Article

\title{
Anaerobic Methane Oxidation in High-Arctic Alaskan Peatlands as a Significant Control on $\mathrm{Net} \mathrm{CH}_{4}$ Fluxes
}

\author{
Kimberley E. Miller ${ }^{1,2,3, *}$, Chun-Ta Lai ${ }^{1}$, Randy A. Dahlgren ${ }^{2}$ and David A. Lipson ${ }^{1}$ \\ 1 Department of Biology, San Diego State University, San Diego, CA 92182, USA; \\ chun-ta.lai@sdsu.edu (C.-T.L.); dlipson@sdsu.edu (D.A.L.) \\ 2 Department of Land, Air and Water Resources, University of California, Davis, CA 95616, USA; \\ radahlgren@ucdavis.edu \\ 3 Voinovich School of Leadership and Public Affairs, Ohio University, The Ridges Building 22, Athens, \\ $\mathrm{OH} 45701$, USA \\ * Correspondence: millerk8@ohio.edu; Tel.: +1-740-566-7048
}

Received: 1 November 2018; Accepted: 28 December 2018; Published: 9 January 2019

\begin{abstract}
Terrestrial consumption of the potent greenhouse gas methane $\left(\mathrm{CH}_{4}\right)$ is a critical aspect of the future climate, as $\mathrm{CH}_{4}$ concentrations in the atmosphere are projected to play an increasingly important role in global climate forcing. Anaerobic oxidation of methane (AOM) has only recently been considered a relevant control on methane fluxes from terrestrial systems. We performed in vitro anoxic incubations of intact peat from Utqiagivik (Barrow), Alaska using stable isotope tracers. Our results showed an average potential AOM rate of $15.0 \mathrm{nmol} \mathrm{cm}^{3} \mathrm{~h}^{-1}$, surpassing the average rate of gross $\mathrm{CH}_{4}$ production $\left(6.0 \mathrm{nmol} \mathrm{cm}^{3} \mathrm{~h}^{-1}\right)$. AOM and $\mathrm{CH}_{4}$ production rates were positively correlated. While $\mathrm{CH}_{4}$ production was insensitive to additions of $\mathrm{Fe}(\mathrm{III})$, there was a depth:Fe(III) interaction in the kinetic reaction rate constant for AOM, suggestive of stimulation by $\mathrm{Fe}(\mathrm{III})$, particularly in shallow soils $(<10 \mathrm{~cm})$. We estimate AOM would consume $25-34 \% \mathrm{of}^{\mathrm{CH}_{4}}$ produced under ambient conditions. Soil genetic surveys showed phylogenetic links between soil microbes and known anaerobic methanotrophs in ANME groups 2 and 3. These results suggest a prevalent role of AOM to net $\mathrm{CH}_{4}$ fluxes from Arctic peatland ecosystems, and a probable link with $\mathrm{Fe}(\mathrm{III})$-reduction.
\end{abstract}

Keywords: Arctic Coastal Plain; methane emissions; AOM; ANME; iron; isotope pool dilution; drained thaw lake basin; metal-dependent AOM

\section{Introduction}

Anaerobic oxidation of methane (AOM) affects global climate, as it constrains the atmospheric release of the powerful greenhouse gas methane $\left(\mathrm{CH}_{4}\right)$. In marine systems, AOM linked to sulfate-reduction consumes approximately $90 \%$ of methane before it can be released into the atmosphere [1,2]. In terrestrial systems, there is increasing evidence that AOM plays a similar role in controlling net $\mathrm{CH}_{4}$ fluxes from soils and freshwater systems [3-5]. The Arctic contains vast quantities of soil organic carbon, much of which is increasingly vulnerable to mobilization as soils warm and permafrost thaws [6]. Global climate change is disproportionately warming Arctic systems, enhancing the likelihood of changes in net greenhouse gas fluxes to the atmosphere from warming soils [7]. Northern peatlands traditionally act as sinks of carbon dioxide $\left(\mathrm{CO}_{2}\right)$ and sources of $\mathrm{CH}_{4}$ to the atmosphere [8-10]. Estimates of the AOM pathway and its impact on net ecosystem $\mathrm{CH}_{4}$ balance within intact northern soils are limited [3,11-15], highlighting the need for additional studies to determine the role of $\mathrm{AOM}$ in $\mathrm{CH}_{4}$ cycling in northern peatlands.

A number of mechanisms have been identified for the AOM process. Marine AOM is most commonly linked with sulfate-reduction, conducted by either a single sulfate-reducing bacterium 
or via the consortium of a sulfate-reducing bacterium and a methanotrophic archaeal partner [1]. For terrestrial systems, AOM is often not related to sulfate reduction, as electron acceptors other than sulfate are more abundant and energetically favorable [16]. Recent work in terrestrial systems has found evidence for AOM associated with non-sulfate terminal electron acceptors [3,11,17-21], including a number of studies identifying a potential linkage to iron-reduction $[17,20,22-25]$, which may be highly relevant to the Fe-rich oligotrophic soils found on the Arctic Coastal Plain. While the drivers of terrestrial AOM and their interactions with electron acceptors are still somewhat confounded, alternative electron acceptors are known to inhibit methanogenesis [26-28] directly via microbial competition [29], and/or indirectly through toxic intermediate products like $\mathrm{NO}_{2}{ }^{-}$[30]. Regardless, alternative electron acceptors could suppress net $\mathrm{CH}_{4}$ flux through $\mathrm{AOM}$, even if they do not directly inhibit methanogenesis.

Advances in the genetic characterization of the AOM pathway have given us a means for identifying the presence and activity of AOM-associated organisms, including $16 \mathrm{~S}$ rRNA and functional genes such as pmoA, pMMO, and mmoX, which code for methanotrophic-specific enzymes [3,31,32]. In marine systems, archeal methanotrophs, also known as "ANME" for ANaerobic MEthanotroph, have been differentiated into the phylogenetically-distinct groups ANME-1 (with subgroups a and $b$ ), ANME-2 (with subgroups $a, b$, and c), and ANME-3 [1,33]. The ANME groups do not cover all known members of the AOM community, particularly in terrestrial and some extreme environments [34,35], but they have been shown to display some interesting functional characteristics. For example, Mohanty et al. [36] found type I methanotrophs were stimulated by nitrogenous fertilizers, while type II were inhibited. Further, Knoblauch et al. [37] saw a shift from type I to type II aerobic methanotrophs in Siberian peat under warming conditions.

Despite recent advances in our understanding of the mechanisms and organisms associated with terrestrial AOM, relatively few studies have measured AOM rates in Arctic systems. The drained thaw lake basin landscapes on the North Slope of Alaska offer a unique location for the measurement of terrestrial AOM. The landscape is populated with vegetated drained thermokarst lake basins (hereafter referred to as "basins"), underlain by deep continuous permafrost that create a natural chronosequence of soil development [38,39]. As basins age, the depth of the surface organic layer grows, reducing contact with the iron ( $\mathrm{Fe}$ )-rich mineral layer. The active layer constitutes the seasonally unfrozen surface soils that contain material available to biological processes and contribute to ecosystem respiration and $\mathrm{CH}_{4}$ flux. Measurements of ecosystem respiration within the basins show high Fe-reduction rates, high native loads of iron, and low or non-measurable amounts of nitrate and sulfate electron acceptors when active layer soils are thawed [40]. The basins are currently net sources of $\mathrm{CH}_{4}$ to the atmosphere. This system is, however, projected to become wetter and warmer with climate change [41,42], a condition likely to enhance $\mathrm{CH}_{4}$ production as new basins develop [39,43]. As AOM is a substrate limited process, increased $\mathrm{CH}_{4}$ production may in turn enhance conditions for $\mathrm{AOM}[13,31,44]$, yet no studies exist that investigate the role of AOM in high-Arctic $\mathrm{CH}_{4}$ production.

Current methods for in situ rate estimates of $\mathrm{CH}_{4}$ production and oxidation involve the combination of stable isotopes and methanogenic inhibition chemicals $[45,46]$. Given evidence that methanogenic inhibition chemicals do, in fact, impact AOM in both culture and environmental samples [47-49], the best available method for determining AOM rates and relative importance to net $\mathrm{CH}_{4}$ flux is in vitro incubation [12]. Laboratory incubations of intact soils ride the line between realistic [50] and controllable.

To our understanding, there are no previously-published AOM rates within high Arctic peatland systems [15]. Our research was motivated by field-based evidence of net $\mathrm{CH}_{4}$ flux suppression by $\mathrm{Fe}$ and humic substances, with an unknown mechanism: inhibition of methanogenesis or stimulation of AOM [51]. To determine the importance of AOM to net $\mathrm{CH}_{4}$ fluxes in high Arctic wetland systems and the influence of inorganic electron acceptors on AOM rates, we performed in vitro incubations of active layer peat soils. We amended soils with treatments of sulfate $\left(\mathrm{SO}_{4}{ }^{2-}\right)$ and ferric iron (Fe(III)-nitrilotriacetic acid). Given the importance of Fe reduction to the anaerobic carbon cycle 
in these soils, we hypothesize that increased Fe(III) will stimulate AOM in this system, impacting overall $\mathrm{CH}_{4}$ flux from the soils. We also present genetic data from basin soils to confirm the presence of microorganisms related to known anaerobic methanotrophs.

\section{Materials and Methods}

\subsection{Study System}

Soils were collected from sites located within the Barrow Environmental Observatory research reserve near Utqiagvik, AK (71.2963 N, 156.5891 W) [39,52]. The Alaskan North Slope landscape is dominated by drained thaw lake basins, which are the footprints of shallow thermokarst lakes that have vegetated since draining [39]. The basins represent a successional chronosequence, commonly categorized into four age classes based on time since draining: young (0-50 years), medium (50-300 years), old (300-2500 years), and ancient (2500-5000 years) [38,39]. Basin succession has been linked to soil productivity, with a strong relationship with organic matter content, bulk density, Fe content, and soil respiration [38,40,52-54]. As basin age increases, organic matter accretion grows the depth of the organic soil layer over time, increasing the distance between the surface and the mineral soil layers. In young and medium age classes the shallow, less-developed soils have relatively high rates of $\mathrm{CH}_{4}$ production and net flux to the atmosphere, with thinner organic layers, lower organic matter content, and higher bulk density in the active layer $[53,55,56]$. There is also low availability of sulfate and nitrate electron acceptors in the acidic and anoxic peat soils in the Arctic, where nutrients are scarce and biological uptake is fast and competitive. Basic soil and porewater data from the cores used in this study are presented in Table 1, as measured by methods outlined in Lipson et al. [40]. For more depth-specific information on Utqiagvik soils, see Lipson et al. 2010 and 2013 [40,52].

Table 1. Average basin soil characteristics used in incubation.

\begin{tabular}{cccccccc}
\hline $\begin{array}{c}\text { Basin Age } \\
\text { Class }\end{array}$ & $\begin{array}{c}\text { Bulk } \\
\text { Density } \\
\left(\mathbf{g} \cdot \mathbf{c m}^{-3}\right)\end{array}$ & $\begin{array}{c}\text { Organic Matter } \\
\text { Content }\left(\mathbf{g} \cdot \mathbf{g}^{-1}\right)\end{array}$ & $\begin{array}{c}\mathbf{F e}^{3+} \\
\left(\mu \mathbf{m o l} \cdot \mathbf{c m}^{-3}\right)\end{array}$ & $\mathbf{p H}$ & $\begin{array}{c}\text { Dissolved } \\
\text { Organic Content } \\
\left(\mathbf{m g} \cdot \mathbf{L}^{-1}\right)\end{array}$ & $\mathbf{C H}_{\mathbf{4}}(\mu \mathrm{M})$ & $\mathbf{C O} \mathbf{2}(\mu \mathrm{M})$ \\
\hline Medium & $0.42(0.05)$ & $0.32(0.04)$ & $30.3(5.7)$ & $5.54(0.1)$ & $30.3(6.1)$ & $1.55(0.3)$ & $671(138)$ \\
Young & $0.44(0.06)$ & $0.29(0.03)$ & $14.0(3.2)$ & $5.89(0.2)$ & $42.0(7.6)$ & $2.36(0.9)$ & $1019(378)$ \\
\hline
\end{tabular}

Basic soil (21.6+/- $0.9 \mathrm{~cm}$ deep) and water chemistry $(0-10 \mathrm{~cm}$ depth) for basins sampled for incubations. Values are means and standard errors ( $\mathrm{n}=3$ for each age class). Porewater and $\mathrm{pH}$ data represent averages for June 2011 when soils were collected.

\subsection{Soil Sampling and Incubation Setup}

We performed two discrete incubation experiments. For the first incubation experiment, we used soils from three depths $(5,15$, and $25 \mathrm{~cm})$ along a single representative core from all of the four basin age classes for a total of 12 samples with no replication to quickly determine which basin age class(es) and depths (if any) had measurable or dynamic AOM activity rates. For the second incubation experiment, we used the results from the first experiment to target basin age classes and depths with promising $\mathrm{AOM}$ activity, and explored the interactions between gross $\mathrm{AOM}$ rates, gross rates of $\mathrm{CH}_{4}$ production, and terminal electron acceptor treatments using three replicate cores from each of two basin age classes and 12 depths per core for a total of 72 samples in triplicate. All soils used in both experiments were from soil cores extracted in June 2011 with a $12 \mathrm{~cm}$ diameter SIPRE corer attached to a handheld gas-powered drill. All soils were collected from waterlogged sites, as previous work showed soil $\mathrm{CH}_{4}$ 3- to 5-fold higher in these locations (as opposed to hydrologically mesic soils in micro-topographically raised areas) [53,56,57]. Extracted frozen cores were kept on wet ice in the field, and stored at $-80^{\circ} \mathrm{C}$ within $2 \mathrm{~h}$ of collection. In the lab, $1 \mathrm{~cm}$ thick discs were cut out of each core at specific depths with a band saw, weighed and transferred to 1-L glass Mason jars with metal ring lids modified to contain gas impermeable butyl rubber septa (Geo-Microbial Technologies, Inc., Ochelata, OK, USA) and an anaerobic indicator strip (Anaerotest 115112, Merck Millipore, Burlington, MA, USA). Jars containing 
the intact "pucks" of frozen soils were sealed, the headspace immediately vacuumed for $2 \mathrm{~min}$, and purged with UHP helium gas for $5 \mathrm{~min}$. Jars were wrapped in foil and stored in dark incubators at 10 ${ }^{\circ} \mathrm{C}$ for one week to allow for full soil thaw. Jar headspaces were purge-flushed with ultra-high purity helium (99.999\%) for 2 min every other day, to remove any $\mathrm{O}_{2}$ released or produced upon thaw.

To begin each incubation, an aqueous treatment solution was added to the jar via the septum, the headspace volume was vacuum flushed with UHP helium for $5 \mathrm{~min}$, and then allowed to equilibrate to atmospheric pressure through tubing submerged in $\mathrm{O}_{2}$-free deionized water. After the jar reached atmospheric pressure, a $\mathrm{CH}_{4}$ mixture was injected to create an initial jar headspace of $5 \% \mathrm{CH}_{4}$ with a 5.03 atom percent $(\mathrm{AP} \%)^{13 / 12} \mathrm{C}$ isotopic composition. Jars were incubated at $10^{\circ} \mathrm{C}$ (range: $8-11^{\circ} \mathrm{C}$ ) in the dark. All anaerobic indicator test strips signaled anoxia within the incubation chambers throughout the incubation. Time series samples at $24,336,480,720$, and $960 \mathrm{~h}$ (i.e., 1, 14, 20, 30, and 40 days) were collected into 10-mL glass serum vials fitted with gas-tight 10-mm butyl rubber stoppers and stored in dark refrigeration until analysis.

\subsection{Basin AOM Activity}

To determine ballpark AOM rates, we conducted a small pilot study using the mass and isotopic signature of $\mathrm{CO}_{2}$ in the headspace to indicate AOM activity. The pilot study used a set of three soil depths $(5,15$, and $25 \mathrm{~cm})$ extracted from a single soil core from each of the four basin age classes, for a total of 12 incubations with no replication. No soil amendments were used in the pilot study. Headspace gases were sampled at 24, 48, 120, 216, and $384 \mathrm{~h}$. Headspace samples were analyzed for $\mathrm{CO}_{2}$ concentration (ppmv) and $\delta^{13} \mathrm{CO}_{2}$ at the University of California-Davis Stable Isotope Facility (Davis, CA, USA).

Before the pool dilution experiment, which was designed to quantify rates of AOM activity and $\mathrm{CH}_{4}$ production, we used the pilot study to determine if AOM was occurring in the soil cores. In the case of the pilot study, we only followed the production of ${ }^{13} \mathrm{CO}_{2}$ over time, which must originate from AOM consuming the ${ }^{13} \mathrm{CH}_{4}$ spike. In other words, $\mathrm{AOM}$ must be active if a ${ }^{13} \mathrm{CO}_{2}$ spike is measurable in the headspace. Jar headspaces were established with $5 \%$ of $5.03 \mathrm{AP} \% \mathrm{CH}_{4}$. For calculations, isotopic fractionation associated with the anaerobic fermentation processes was assumed negligible, so the $\delta^{13} \mathrm{C}$ signature of soil respired $\mathrm{CO}_{2}$ was essentially the isotopic signature of the substrate (which was given a value of $-24 \%$ based on recent work in Utqiagivik, AK, USA) [58]. Non-methanotrophic anaerobic soil respiration is expected to gradually decrease headspace ${ }^{13} \mathrm{CO}_{2}$ while increasing overall $\mathrm{CO}_{2}$ concentration. AOM, if present, consumes spiked ${ }^{13} \mathrm{CH}_{4}$, increasing headspace ${ }^{13} \mathrm{CO}_{2}$ and $\mathrm{CO}_{2}$ mass. Hydrogenotrophic methanogenesis could utilize some of the ${ }^{13} \mathrm{CO}_{2}$ produced by $\mathrm{AOM}$, however, we ignored this possible feedback as our experiments were not long in duration, and by assuming null methane production we underestimated the rate of ${ }^{13} \mathrm{CO}_{2}$ reduction. Using mass balance equations for total $\mathrm{CO}_{2}$ and assuming ${ }^{13} \mathrm{CO}_{2}$ fractionation factors for $\mathrm{AOM}$ and anaerobic soil respiration, we calculated the amount of $\mathrm{CO}_{2}$ produced by $\mathrm{AOM}$ using an isotope mixing model. AOM rates were calculated as the change in mass of $\mathrm{AOM}$-produced $\mathrm{CO}_{2}$ versus incubation time.

\section{4. $\mathrm{CH}_{4}$ and $\mathrm{AOM}$ Rate Estimates}

We estimated gross $\mathrm{CH}_{4}$ production and consumption (AOM) rates using an isotope pool dilution method slightly modified from von Fischer and Hedin [45] and Smemo and Yavitt [13]. Using mass balance equations and an isotope mixing model, this technique allows us to simultaneously calculate gross methanogenesis and AOM rates.

The isotope pool dilution begins with an initial spike of ${ }^{13} \mathrm{C}$-enriched $\mathrm{CH}_{4}$ in the headspace of an incubation jar. Subsequently, the amount of ${ }^{13} \mathrm{CH}_{4}$ in the headspace decreases by two processes: (1) diffusive flow of the labeled substrate into the soil [45], and (2) ${ }^{13} \mathrm{CH}_{4}$ consumption by AOM. The latter in turn releases ${ }^{13} \mathrm{CO}_{2}$, representing the only significant source of ${ }^{13} \mathrm{C}$-enriched $\mathrm{CO}_{2}$ into the headspace. Methanogenesis, on the other hand, produces and releases mostly ${ }^{12} \mathrm{CH}_{4}$ and ${ }^{12} \mathrm{CO}_{2}$ into the headspace, while anaerobic soil respiration contributes predominantly ${ }^{12} \mathrm{CO}_{2}$ into the headspace. 
Over time, the isotope ratios of headspace $\mathrm{CH}_{4}$ should decrease as AOM continues to draw down ${ }^{13} \mathrm{CH}_{4}$ from the initial spike. Total mass of $\mathrm{CH}_{4}$ also changes over time depending on the balance between $\mathrm{CH}_{4}$ production and consumption (i.e., headspace $\mathrm{CH}_{4}$ mass increases over time if $\mathrm{P}>\mathrm{C}$ ). Labeled ${ }^{13} \mathrm{C}$ was expressed as atom percent (AP\%) in all calculations.

$\mathrm{CH}_{4}$ mass and isotope data were used to calculate an incubation-specific, first-order reaction rate constant $(k)$ for gross $\mathrm{CH}_{4}$ consumption. In these calculations, we assumed an isotopic signature of newly produced $\mathrm{CH}_{4}$ of $-60 \%$, or $1.05 \mathrm{AP} \%[13,45,59]$. The isotope fractionation of AOM has estimates ranging from -2 to $-14 \%$ in terrestrial systems [13,60-62]. We used a conservative estimate for this effect using a value of $0 \%$ in our calculations. Given our $0 \%$ assumption, we cannot overestimate the effect of AOM. All mass values were standardized to a dry soil weight basis. $\mathrm{Net}^{\mathrm{CH}_{4}}$ fluxes were calculated as the rate of $\mathrm{CH}_{4}$ mass change over time. Calculations of gross $\mathrm{CH}_{4}$ consumption and net $\mathrm{CH}_{4}$ flux rates were taken over the entire incubation period. Gross $\mathrm{CH}_{4}$ production rates were calculated by Net Flux $=$ Production - Consumption, as the sum of gross consumption and net $\mathrm{CH}_{4}$ flux rates.

A small number of incubation jars showed positive net increase in $\mathrm{CH}_{4} \mathrm{AP} \%$. The magnitude was small and often within the range of instrument precision $(\sim 0.0357 \%)$. Those results were considered unreliable and were excluded from rate analyses. This is because $\mathrm{CH}_{4} \mathrm{AP} \%$ can either decrease or see little change during incubation, but not increase. A continuous decline in headspace ${ }^{13} \mathrm{CH}_{4}$ is expected in the presence of AOM. Without AOM, headspace ${ }^{13} \mathrm{CH}_{4}$ is likely to decrease initially as a small fraction of ${ }^{13} \mathrm{CH}_{4}$ diffuses into soil pore space. When jars with increasing $\mathrm{CH}_{4} \mathrm{AP} \%$ were used in the calculation, we arrived at zero $\mathrm{CH}_{4}$ production. These results were inconsistent with total mass observation in which significant increases in $\mathrm{CH}_{4}$ production were measured at the end of the incubation.

\subsection{Treatments}

To characterize potential AOM rates more broadly, we incubated a total of 72 soil samples taken from a total of six cores of waterlogged depressions within young and medium age class basins, three from each basin age class. The effect of depth on AOM rates in the pilot study was unclear, thus for this experiment, twelve depths were sampled from each core ranging from 1 to $30 \mathrm{~cm}$ below the surface, resulting in the following replication: two basin age classes $x$ three basins per age class $x$ 12 depths per core. To determine the effect of electron acceptors on both methanogenic and AOM rates, treatments of DI water, iron (Fe(III)-nitrilotriacetic acid, or Fe(III)-NTA) and sulfate $\left(\mathrm{K}_{2} \mathrm{SO}_{4}\right)$ were used to alter the amount of available electron acceptors present in incubated soils. Fe-NTA has been used as an electron acceptor in multiple studies of Fe reducers as it is used by common ones such as Geobacter, Shewanella, and Rhodoferax $[63,64]$. We created common volume treatment solutions using the average frozen weight of incubated soils and basin-specific soil water content. Treatments were designed to deliver equal amounts of electron accepting capacity, resulting in final soil concentrations of $8 \mathrm{mM}$ $\mathrm{Fe}(\mathrm{III})-\mathrm{NTA}$ and $1 \mathrm{mM} \mathrm{K}_{2} \mathrm{SO}_{4}$. Autoclaved treatment solutions were bubbled with UHP helium for $10 \mathrm{~min}$, capped and stored in serum vials with UHP helium headspaces at $10^{\circ} \mathrm{C}$ for less than $12 \mathrm{~h}$ before administration. We excluded a nitrate treatment, despite evidence of a nitrate-dependent AOM pathway in other systems $[18,65]$. This was done in deference to the low availability of nitrate found in past research in Utqiagivik soils, and the possible inhibitory effect nitrogen can have on methanogenesis rates $[13,30]$.

The three treatments were administered in a stratified block design, blocked by core, and stratified into 4 depth classes: top $(0-1,2-3,5-6 \mathrm{~cm})$, top-middle $(8-9,9-10,11-12 \mathrm{~cm})$, bottom-middle (14-15, $17-18,20-21 \mathrm{~cm})$, and bottom $(23-24,26-27,29-30 \mathrm{~cm})$. Electron acceptor treatments were randomly assigned within each depth class. Samples of headspace gas from each jar were drawn after 24, 336, 480, 720, and $960 \mathrm{~h}$ of incubation. Mass and $\delta^{13} \mathrm{C}_{\text {of }} \mathrm{CH}_{4}$ gas in the headspace were measured at the Stable Isotope Facility of the University of California-Davis using a ThermoScientific PreCon-GasBench system interfaced to a ThermoScientific Delta V Plus isotope ratio mass spectrometer (ThermoScientific, 
Bremen, $\mathrm{DE}, 0.0357 \%$ or $0.2 \%$ instrument precision). Headspace $\mathrm{CO}_{2}$ mass and isotopic signatures are not needed for rate estimations using the pool dilution method, and were not measured in the full experiment.

\subsection{Molecular Analysis}

We used two datasets (16S rRNA gene sequences and random shotgun metagenomes) to identify gene sequences from Utqiagivik soils that are closely related to microbes capable of AOM. 16S rRNA sequences were obtained from the Earth Microbiome Project (EMP) [66]. This study used soil samples of varying depths from the rims and centers of low-centered polygons of old and ancient basins, sampling a total of 12 locations (six basins $x$ high vs. low) times three depths, minus one sample that was lost, for a total of 35 libraries [67]. Sample processing, sequencing, and core amplicon data analyses were performed by the EMP (www.earthmicrobiome.org) and all amplicon and metadata have been made public through the data portal (www.microbio.me/emp). Sequences closely related to ANME groups 1, 2, and 3 [68] were identified by local BLAST of the data set, aligned with known representatives from these groups using the SINA alignment tool (www.arb-silva.de/aligner/) [69], and a maximum likelihood phylogenetic tree was generated using the Fast DNAml application within BioEdit [70].

The metagenomic analysis used the libraries described by Lipson et al. [71]. These represent soils of varying depths from a single medium-aged basin. MG-RAST was used to search for mcrA genes, and the relationships of these sequences to mcrA genes from known ANME clades [72-74] was explored using a protein maximum likelihood tree (PROml) with amino acid sequences aligned using CLUSTALW in Bioedit [70].

\subsection{Statistical Analyses}

Most data were unbalanced due to unequal sample sizes after data screening and were therefore evaluated using the Type III sum of squares from multi-way ANOVA and ANCOVAs, with post-hoc determinations by one-way ANOVA and Tukey honest significant difference tests (both of which are less sensitive to unequal sample size). Soil depths were analyzed as a continuous variable, while depth class was treated as a categorical variable. We used correlation analysis to compare quantities and rates of methane produced and consumed. When necessary, data were transformed to conform to test assumptions of normality and homogeneity of variance. All statistics were performed with $\mathrm{R}$ version 3.1.1 [75].

\section{Results}

\subsection{AOM-Associated Microbes and Genes}

Phylogenetic analysis of 16s rRNA showed the clustering of Utqiagivik basin soil sequences with known methane-cycling archaea, including ANME groups 2 and 3 (Figure 1). A total of 3306 (out of 2027920) sequences were similar to nitrate-dependent methanotrophs belonging to the phyla NC10. Soils sequenced in this series were exclusively from old and ancient age class basins, and so they are not directly related to the soils incubated for AOM and methanogenesis rates. However, recent studies using 16s rRNA gene sequences in this landscape have shown the ubiquity of methanogen communities and a convergence in microbial composition within the active layer, regardless of basin age class [76]. Therefore, differences in microbial communities between age classes in this ecosystem appear to be more subtle than changes associated with soil depth and microtopography $[40,71,77]$. 


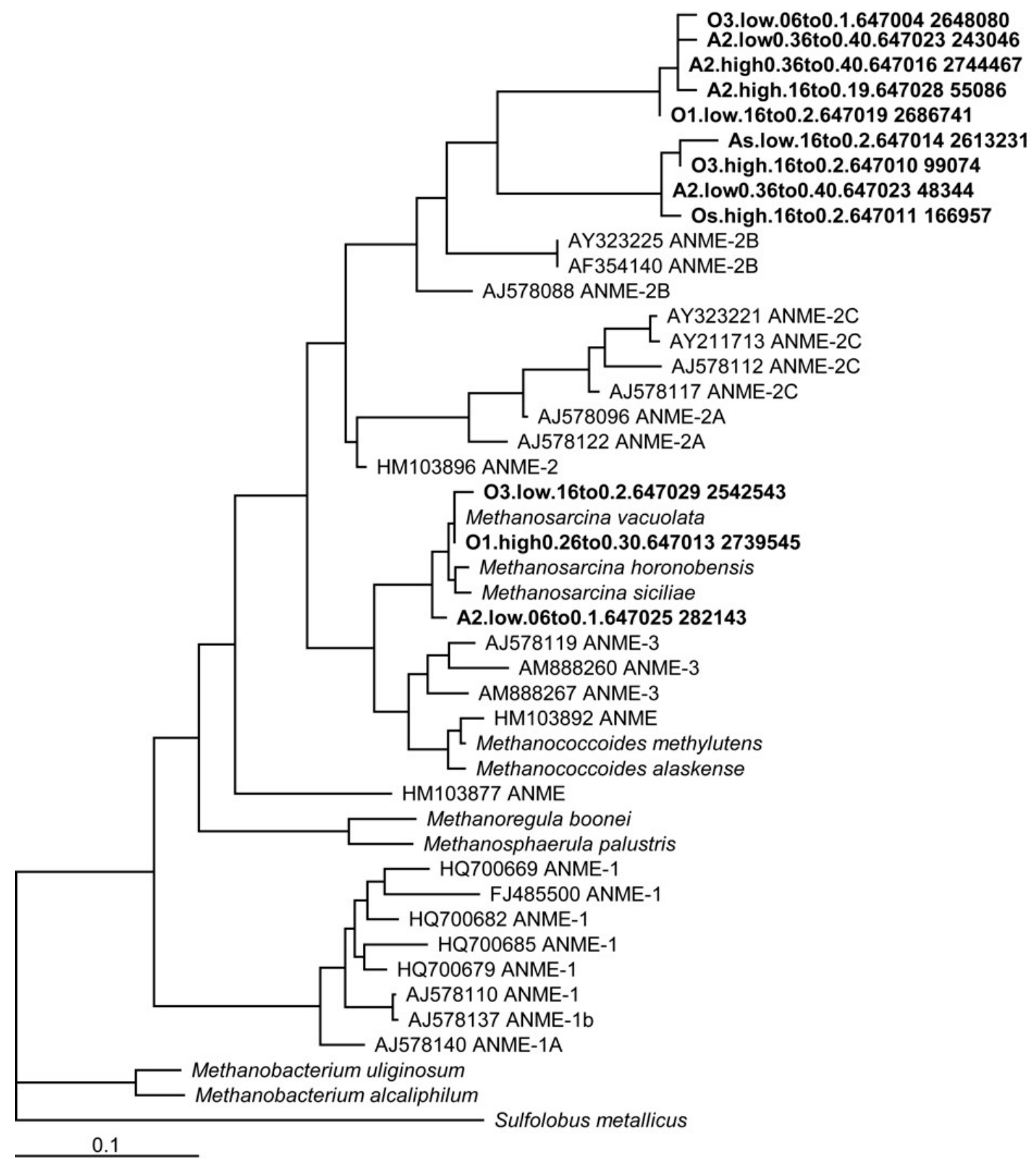

Figure 1. Phylogenetic tree of $16 \mathrm{~S}$ rRNA sequences from the Earth Microbiome Project of old and ancient basins, illustrating the relatedness of organisms found in Utqiagivik soils with other known methane-cycling isolates in ANME groups 2 and 3.

Utqiagivik soil isolates related to methanogens capable of Fe(III)-reduction were detected [63], namely the Methanosarcina, Methanobacterium palustre, and Methanococcus clades (Figure 2), grouping closely amongst ANME groups 2 and 3, with greater separation from the ANME group 1. 


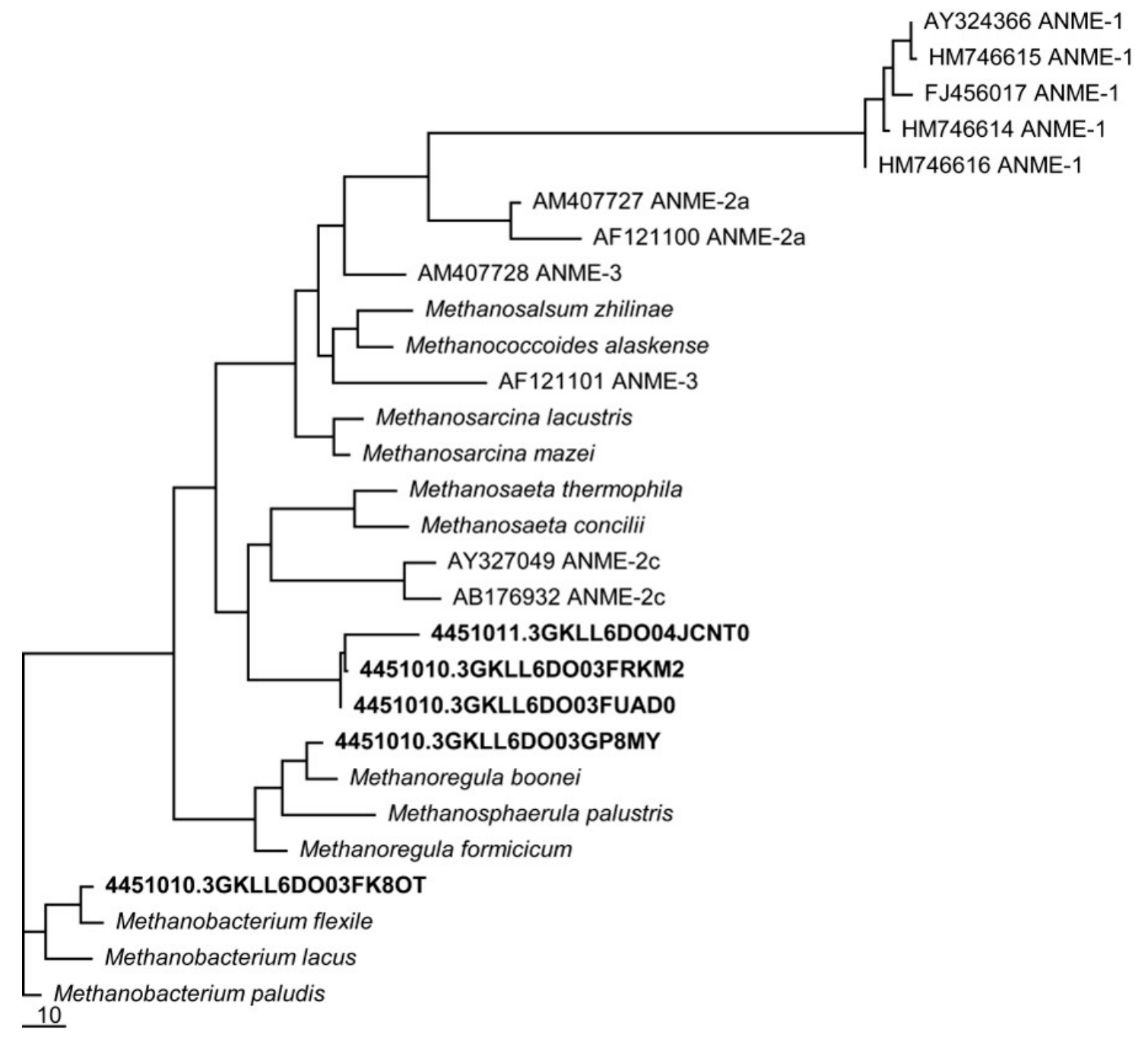

Figure 2. Phylogenetic tree of mcrA genes from the metagenomes of a single medium-aged basin. Utqiagivik sequences cluster near mcrA genes known to be associated with the "reverse methanogenesis" pathway of $\mathrm{CH}_{4}$ consumption.

\subsection{Pilot Study}

All data in the pilot study showed linear trends of increasing $\mathrm{CO}_{2}$ mass and $\delta^{13} \mathrm{CO}_{2}$ over time, indicating AOM activities within incubated soil cores from all age classes. The relative importance of AOM measured during the pilot study was greatest in young and medium age basin soils, but the two age classes had an inconsistent relationship with soil depth (Figure 3). Basin age class and soil depth were most strongly related to total $\mathrm{CO}_{2}$ flux rates ( $p=0.018$ and 0.006 , respectively). There was also an interaction of soil depth $\mathrm{x}$ basin age class with AOM rates (interaction $p=0.078$ ), with lower AOM rates found in the deeper layers of old and ancient basins (Figure 3). 


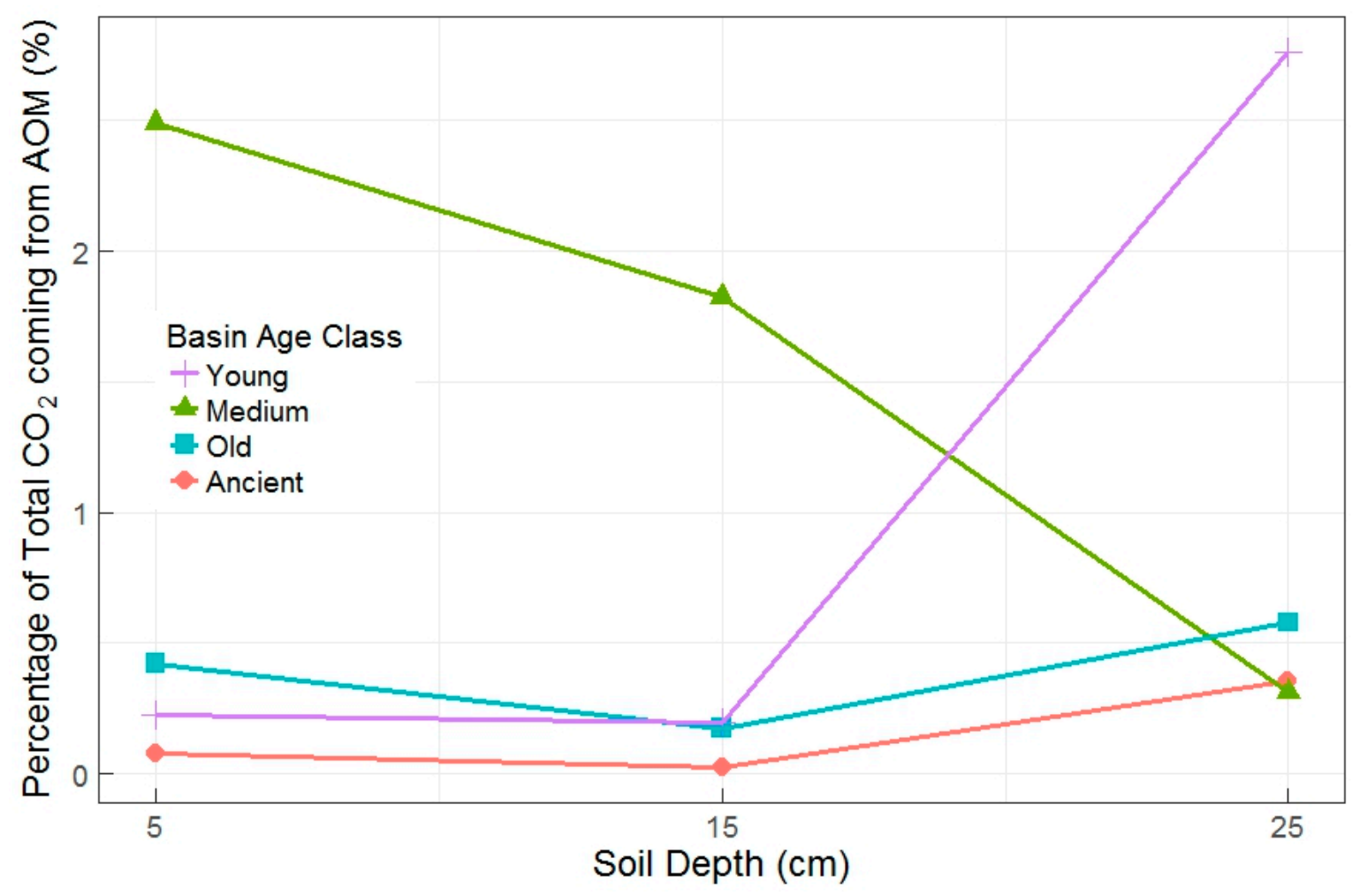

Figure 3. Percentage of total $\mathrm{CO}_{2}$ attributed to AOM by basin age class and soil depth in the pilot experiment. Proportions represent total amount of $\mathrm{CO}_{2}$ from AOM relative to total amount of $\mathrm{CO}_{2}$ evolved over the course of the incubation (all $384 \mathrm{~h}$ ). There is one incubation represented per age class and depth interaction $(n=12)$.

Four of the twelve pilot jars were significantly different than the others in terms of either AOM rates and/or the ratio of $\mathrm{AOMCO}$ to total $\mathrm{CO}_{2}$ production. The highest $\mathrm{AOM}$ rates were measured in soils from the old basin at $5 \mathrm{~cm}$, the medium basin at $5 \mathrm{~cm}$, and the young basin at $25 \mathrm{~cm}$. The three highest values for the percentage of total $\mathrm{CO}_{2}$ coming from $\mathrm{AOM}$ were from the medium basin at $15 \mathrm{~cm}$, the medium basin at $5 \mathrm{~cm}$, and the young basin at $25 \mathrm{~cm}$. Total $\mathrm{CO}_{2}$ flux rates were also lower in the young and medium basins (independent of depth). The most dynamic (and often the highest) AOM rates were in soils from young and medium basins, thus, we sampled from only young and medium basins for the full experiment.

\subsection{Methane Production and Consumption Rates}

The primary objectives in the full experiment were to determine if the AOM pathway was an important aspect of soil carbon cycling in this system, and to determine possible drivers of differences in gross $\mathrm{CH}_{4}$ production and consumption rates (Figure 4). We found a moderate correlation between the two gross rates, with an overall $R^{2}=0.51(p<0.001)$ upon removal of a single outlier (consumption rate $<1 \mathrm{nmol} \mathrm{CH}_{4}-\mathrm{C} \mathrm{cm}^{-3} \mathrm{~h}^{-1}$ ). Consumption rates were higher than production rates (overall linear regression slope $=0.34$, and $\mathrm{y}$-intercept $=2.55$ ), demonstrating that $\mathrm{AOM}$ can eclipse methanogenesis in closed laboratory incubations. This effect was similar between young and medium age classes, which had indistinguishable linear relationships between production and consumption rates (ANOVA $p=0.4911)$. 


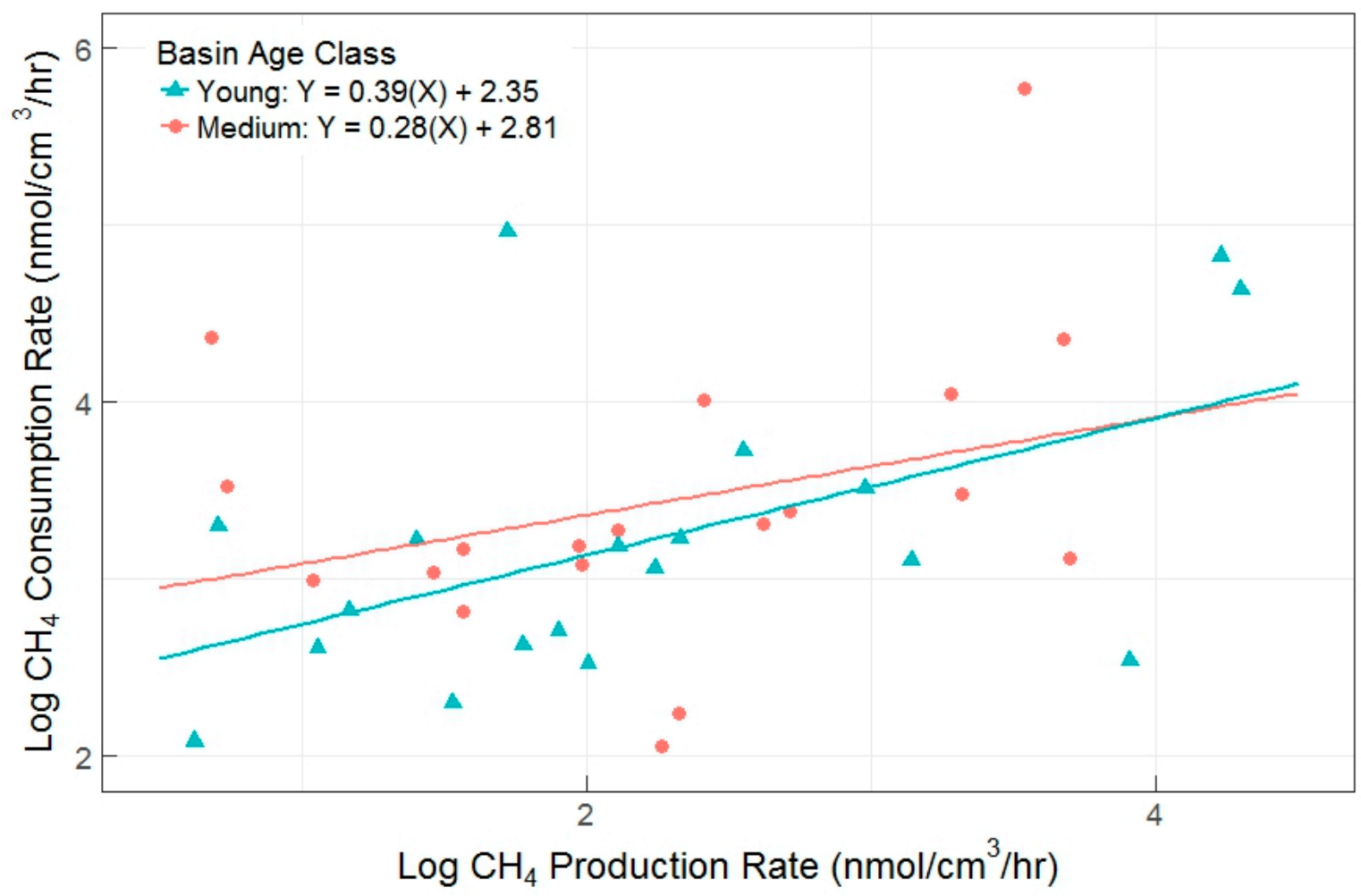

Figure 4. Gross $\mathrm{CH}_{4}$ production versus gross consumption rates $\left(\mathrm{R}^{2}=0.51, p<0.001\right)$ for young and medium basin age classes. Each data point represents results from a single incubation, with all incubations represented.

\subsection{Basin, Depth and Treatment Effects}

There were no statistically significant differences among basins and basin age classes in any of the $\mathrm{CH}_{4}$ flux metrics (net flux, gross consumption, and gross production). In the pilot study, we did not find a clear relationship between depth and AOM rates. Similarly in the full experiment, AOM rates did not show a relationship with soil depth, but gross $\mathrm{CH}_{4}$ production rates significantly decreased by a factor of 3 with increasing depth (Figure 5).

When soil depth was binned into four sequential depth classes as a blocking factor during random treatment assignment, deeper soil layers were related to lower gross production rates $(p=0.015)$, but were not significantly linked with gross consumption rates. There was also not a significant change in net $\mathrm{CH}_{4}$ fluxes by depth class, regardless of a visual pattern (Figure 6). Despite a lack of overall significance in depth class on net $\mathrm{CH}_{4}$ fluxes, there was a significant difference between the $\mathrm{Fe}(\mathrm{III})-\mathrm{NTA}$ and sulfate treatments within the 7-14 cm depth class, with higher AOM rates and $\mathrm{CH}_{4}$ production rates found in the Fe-treated soils. The production to consumption ratio ( $\mathrm{P}: \mathrm{C}$, Table 2) indicated there is a proportional increase in production and consumption as a result of Fe-treatment in this depth class. Figure 6 exhibits the prevalence of net $\mathrm{CH}_{4}$ oxidation in these soils (or the potential thereof), which were further enhanced by the treatment effect. We discovered no difference in net fluxes by depth or treatment between the sulfate and control treatments, but significant effects of depth, treatment, and the depth $\mathrm{x}$ treatment interaction between the control and Fe(III)-treated net fluxes $(p=0.03,0.02$, and 0.02 , respectively). These patterns held true when using depth class (Figure 6). 


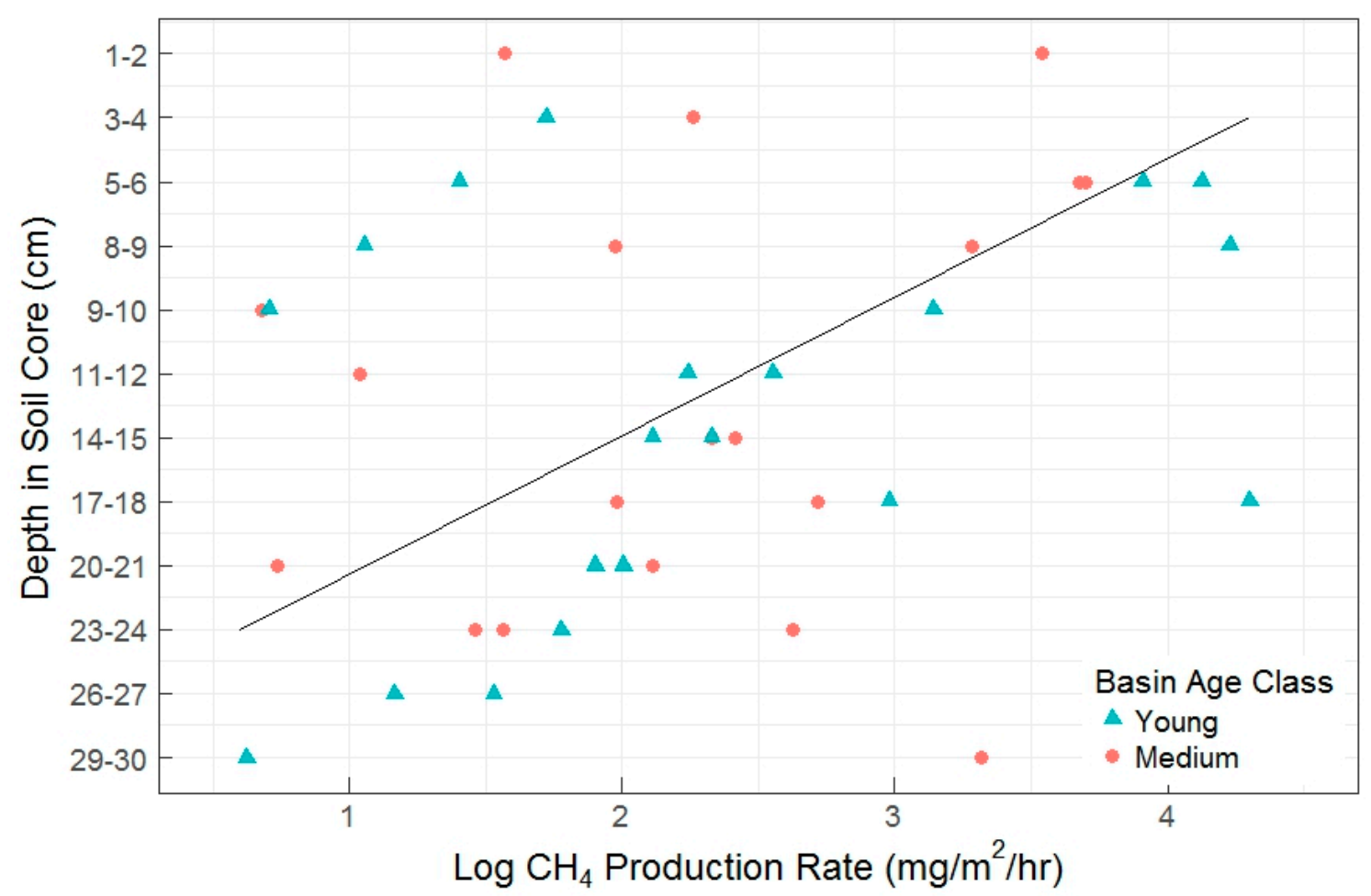

Figure 5. Gross $\mathrm{CH}_{4}$ production rate by soil depth measured in the full experiment. Each data point represents a single incubation. Depth in soil core is oriented along the y-axis with soil surface at top. Also shown is a linear fit line $\left(R^{2}=0.22, p=0.06\right)$.

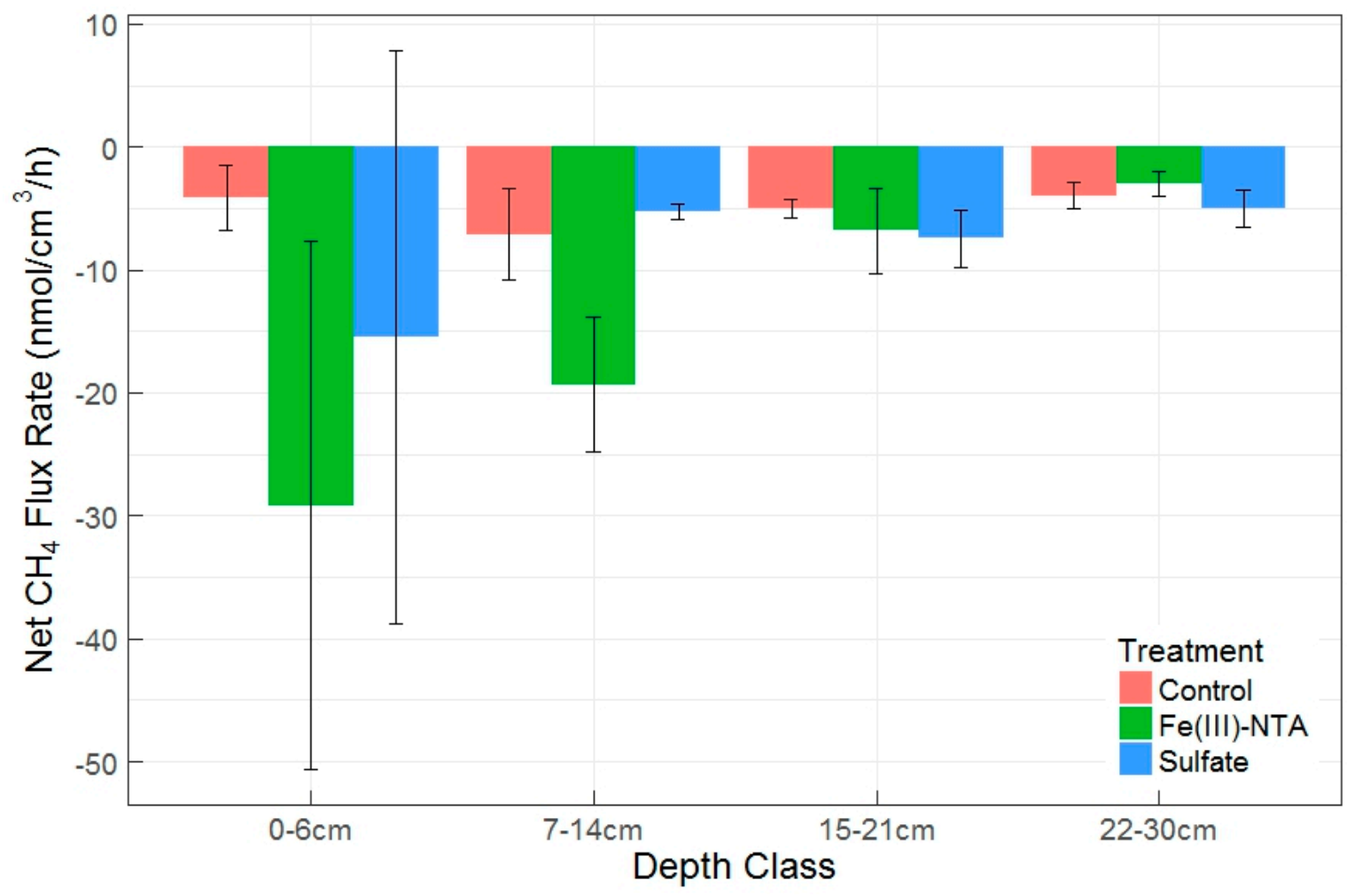

Figure 6. Mean $\pm \mathrm{SEM}$ net $\mathrm{CH}_{4}$ flux rates by depth class and electron acceptor treatment. Negative values denote oxidation/consumption. Different letters above each treatment within each depth class denote significant differences by Tukey test $(p<0.05)$. 
With the exception of gross production, $\mathrm{CH}_{4}$ flux rates were not significantly explained by depth, depth class, or electron acceptor treatment (Table 2, ANOVA). Blocking by depth class, we found $\mathrm{CH}_{4}$ flux rates and $k$ were not significantly altered by electron acceptor treatments, with the lack of treatment effect due to the relative insensitivity found in the bottom half of depth treatments. The ratio of gross production to gross consumption (P:C) did not significantly vary by depth or treatment.

Average gross production rates within sulfate-treated soils were distinguishable by depth classes $(p=0.003)$, with an overall decrease in rates with increasing depth. Within the sulfate-treated soils, the effect of depth class on gross production was significant (ANOVA $p=0.01$ ). The sulfate:depth effect is absent in the P:C ratio, with an exception in the $0-6 \mathrm{~cm}$ depth, which had a marginally higher $\mathrm{P}: \mathrm{C}$ than all other sulfate depth classes (ANOVA $p=0.09$ ).

Table 2. Methane cycling rates by depth class and acceptor addition treatment.

\begin{tabular}{|c|c|c|c|c|}
\hline & $\begin{array}{l}\text { Gross Production } \\
\text { (nmol C-CH } 4 / \mathrm{cm}^{3} \\
\text { dry soil/hour) }\end{array}$ & $\begin{array}{l}\text { Gross Consumption } \\
\text { (nmol C-CH }{ }_{4} / \mathrm{cm}^{3} \text { dry } \\
\text { soil/hour) }\end{array}$ & $\begin{array}{l}\text { Production to } \\
\text { Consumption } \\
\text { Ratio (P:C) }\end{array}$ & $k\left(\right.$ day $\left.^{-1}\right)$ \\
\hline $0-6 \mathrm{~cm}$ & a & & & \\
\hline Control & 1.77 & 5.85 & 0.51 & 0.0019 \\
\hline Fe(III)-NTA & 1.78 & 31.0 & 0.10 & 0.0168 \\
\hline Sulfate & 16.6 & 32.1 & $1.6^{\dagger}$ & 0.0083 \\
\hline $7-14 \mathrm{~cm}$ & $\mathrm{ab}$ & & & \\
\hline Control & 7.68 & 14.8 & 0.61 & 0.0039 \\
\hline Fe(III)-NTA & 8.92 & 28.3 & 0.22 & 0.0072 \\
\hline Sulfate & 2.05 & 7.28 & 0.27 & 0.0024 \\
\hline $15-21 \mathrm{~cm}$ & $a b$ & & & \\
\hline Control & 3.86 & 8.91 & 0.42 & 0.0038 \\
\hline Fe(III)-NTA & 3.67 & 10.5 & 0.51 & 0.0040 \\
\hline Sulfate & 9.05 & 16.5 & 0.47 & 0.0068 \\
\hline $22-30 \mathrm{~cm}$ & $\mathrm{~b}$ & & & \\
\hline Control & 3.63 & 7.60 & 0.46 & 0.0035 \\
\hline Fe(III)-NTA & 4.01 & 7.04 & 0.42 & 0.0028 \\
\hline Sulfate & 1.68 & 6.68 & 0.29 & 0.0023 \\
\hline
\end{tabular}

* ANOVA for depth class vs. gross production p-value: 0.015 . Tukey test for gross production by depth class denoted by small letters in the depth class header rows of $1^{\text {st }}$ data column. + Single outlier removed from within this category (>3 s.d. from mean).

In the full ANOVA, the effects of depth and electron acceptor treatment on the first-order rate constant for $\operatorname{AOM}(k)$, were not significant. However, there was a depth effect nested within the iron treatment group, where increasing depth was significantly correlated with decreasing $k$, and thus, lower potential AOM rates (Figure 7). To parse out the effects of the Fe-treatment and soil depth on $k$, we directly compared the Fe and control treatments (leaving the sulfate-treated soils out of the analysis, as they were not distinguishable from the control group $k$ estimates at any depth, but did contribute a high variance obfuscating the model). Including all depth classes, we found a marginal effect of the Fe treatment $(p=0.078)$, and a significant interaction effect between treatment $x$ depth $(p=0.024)$. The treatment $x$ depth interaction was driven by the higher rate constant in Fe-treated shallow soils. Within Fe-treated soils, there was a significant depth effect $(p=0.048)$. 


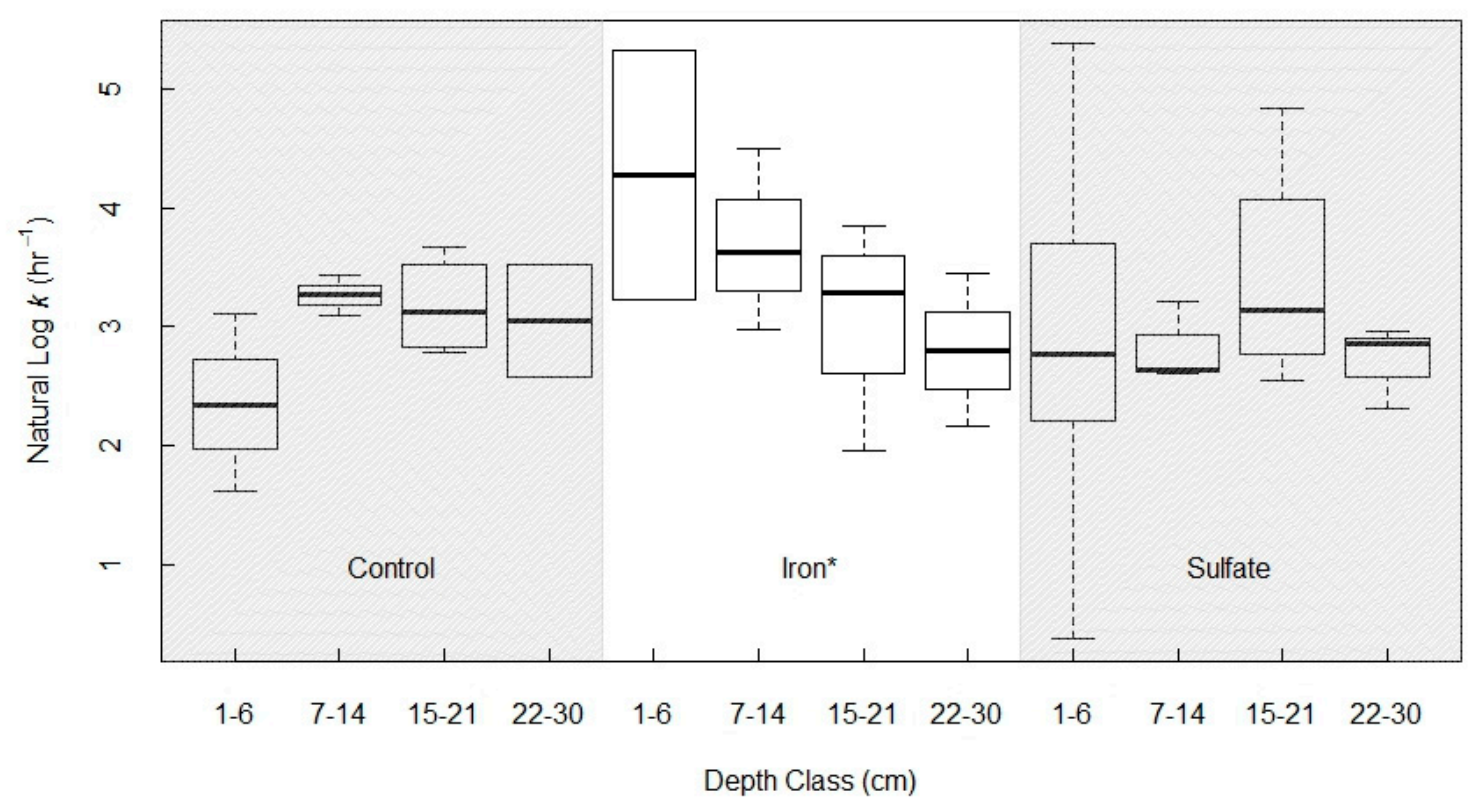

Figure 7. Natural log of gross AOM rate constant $k$ separated by depth class and electron acceptor treatment. There was a significant difference between depth classes within the iron treatment group ( $p=0.048$, ANOVA), and for the depth-by-treatment interaction between the control and iron treatments $(p=0.024)$.

\section{Discussion}

The AOM pathway is gaining momentum in its recognition as a process of potential importance within terrestrial systems. Peatlands in the high Arctic are of particular interest to understanding net terrestrial $\mathrm{CH}_{4}$ fluxes because they act as massive soil carbon storage sites within both the active and permafrost soil layers [6]. This study demonstrated both the presence of AOM-associated microbes and that anaerobic $\mathrm{CH}_{4}$ consumption has the potential to influence $\mathrm{CH}_{4}$ cycling in the basin wetland landscapes of the Alaskan North Slope. Using in vitro soil incubations of intact soils, we quantified AOM rates by two methods: measuring the appearance of ${ }^{13} \mathrm{CO}_{2}$ after incubating soils with a ${ }^{13} \mathrm{CH}_{4}$ headspace spike; and a stable isotope pool dilution technique to simultaneously estimate the rates of methanogenesis and AOM.

\subsection{Presence of Relevant Microbial Communities}

Phylogenetic analysis of Utqiagivik soils showed the presence of known methanotrophs using $16 \mathrm{~S}$ rRNA and mcrA genes associated with the "reverse methanogenesis" pathway, which most closely aligned with anaerobic methanotrophs known as ANME groups 2 and 3. The presence of these organisms in our system serves to confirm that consumption rates measured in the soil incubations were biologically-mediated, and provide some information about the likely functionality of the ANME in these soils.

In addition to the evidence that our soils contain ANME organisms, we also have evidence for the presence and functioning of organisms known to facilitate extracellular electron transfers. Extracellular electron transfer is a capability associated with both ANME-2 [78] and Geobacter [79] microorganisms that can reduce solid electron acceptors like metal oxides. From previous work we know Geobacter is a major contributor to ecosystem respiration from these soils [71,77]. Extracellular electron transfer is a recognized mechanism for metal- and organics-dependent AOM [80], tied functionally to ANME group 2 organisms $[17,20,79]$. This work found organisms closely related to other known methane-cycling isolates in ANME groups 2 and 3 (Figures 1 and 2). The presence of both Geobacter and ANME-2 organisms, in conjunction with evidence of significant levels of methanotrophy during anoxic incubations, supports metal-dependent AOM driven by extracellular electron transfer $[20,78,81]$. 


\subsection{AOM Activity Rates and Importance to $\mathrm{Net}^{\mathrm{CH}_{4}}$ Flux}

Given the potential rates we measured, AOM is a significant sink of methane in the Utqiagivik soils we tested-in most of our closed system incubations, AOM consumed the equivalent mass of biogenic methane during the experiment, leading to our estimates that AOM consumes between $25 \%$ and $34 \%$ of $\mathrm{CH}_{4}$ produced, commensurate with other estimates of AOM effect on net flux rates from freshwater wetlands [82-84].

We observed peak rates of AOM at the outset of the incubation periods, likely an artifact from the $5 \% \mathrm{CH}_{4}$ spike. We designed the incubations with a large, initial dose of $\mathrm{CH}_{4}(5 \%)$ in the headspace in order to address concerns over substrate limitation of the AOM pathway. This decision appears to have indeed promoted AOM activities and initially depressed $\mathrm{CH}_{4}$ production [13], as suggested by an overall intercept of $2.55 \mathrm{nmol} \mathrm{CH}_{4} \mathrm{~cm}^{-1} \mathrm{~h}^{-1}$ in the comparison between consumption and production rates (Figure 4). We posit that the positive intercept represents the artifact effect of the $5 \%$ $\mathrm{CH}_{4}$ spike, but as incubations continued methanogenesis quickly caught up, producing more $\mathrm{CO}_{2}$ substrates. When we combine all young and medium basin data, the regression line represents the ratio of consumption to production as the incubation approaches a quasi-steady state. Using the slope for all incubations (regardless of basin, depth, and treatment), we estimate potential AOM consumption to be approximately $34 \%$ of $\mathrm{CH}_{4}$ production in a highly $\mathrm{CH}_{4}$ concentrated environment.

The potential influence of high $\mathrm{CH}_{4}$ concentrations in the headspace becomes less important with increasing soil depth, where high levels of $\mathrm{CH}_{4}$ are likely commonplace. Within deep anoxic soils, biogenic gas can reach very high concentrations, with published values reaching up to $10 \% \mathrm{CH}_{4}$ [85]. Potential AOM rates were measured under $5 \% \mathrm{CH}_{4}$, but ambient $\mathrm{CH}_{4}$ concentrations in the soil profile may only reach around 5 ppt $(0,5 \%)$ (Lipson, unpublished data). Assuming the AOM rate constant and $\mathrm{CH}_{4}$ production rates found in this study hold for natural conditions, we would expect an AOM rate about $10 \%$ lower than measured in the experiment. Therefore, $1.5 \mathrm{nmol} \mathrm{cm} \mathrm{h}^{-1} \mathrm{CH}_{4}$ consumed by AOM vs $6.0 \mathrm{nmole} \mathrm{cm}^{3} \mathrm{~h}^{-1}$ produced, or $25 \%$ of the total.

The results we present here are based entirely on biological processes, as abiotic uptake of $\mathrm{CH}_{4}$ is not accounted for in our isotope-based rate calculations. Taking abiotic $\mathrm{CH}_{4}$ sorption into account could influence the quantification of the rates presented here [86], and should be a consideration in the planning of future studies of soil $\mathrm{CH}_{4}$ cycling dynamics.

\subsection{Drivers and Stressors}

Since these landscapes act as net sources of $\mathrm{CH}_{4}$ to the atmosphere, we know that production outpaces consumption rates in intact soil systems under current conditions, but how might climate change impact these pathways, and thereby influence overall carbon gas fluxes? The North Slope landscape is likely to become warmer and wetter with climate change [41,42], coincident with thicker active layers as permafrost thaw extends deeper into the transition zone and beyond. With the increased thaw depths leading to thicker active layers, there will be more carbon available for biological processing and losses as net carbon flux to the atmosphere as the greenhouse gases $\mathrm{CO}_{2}$ and $\mathrm{CH}_{4}$ [7]. The role of northern peatland soils to ecosystem $\mathrm{CH}_{4}$ flux is dependent on the complex interaction between microbial populations producing and consuming $\mathrm{CH}_{4}$. We found evidence that Fe enrichment in shallow soils positively influences the rates of AOM, thereby acting as a check on net $\mathrm{CH}_{4}$ flux to the atmosphere.

With warming and increased permafrost thaw depths, the interaction between the organic and mineral soil layers will increase, particularly in the young basin age classes that have the thinnest organic layers and relatively high system productivity. Our results also showed that $\mathrm{CH}_{4}$ flux rates, driven by changes in production rates, varied with depth. The relationship with depth was weak, and could be driven by Fe availability rather than other factors associated with depth, as a discernible pattern was only seen in soils treated with Fe(III). Vaughn et al. [87] found a disconnect between $\mathrm{CH}_{4}$ concentrations in the soil porewater and net flux from the soil surface, explained as a difference in production rates by depth, a difference in transportation rates, and/or different oxidation rates 
in shallow soils. We have evidence supporting a difference in production rates by depth (Table 2), with shallow soils exhibiting the lowest gross production rates. The data we presented here have relatively weak depth effects for most variables, which could be an artifact of the type of soil incubations we performed creating conditions that represent an estimation of reality more likely for some soil layers than for others [50]. Weak depth effects shown in variables like gross production rate (Figure 5, Table 2) are indicative of the complex suite of abiotic and biotic conditions and processes occurring in the soil system.

Our work supports a depth $x$ Fe interaction effect on AOM rates, which could be explained as: (1) $\mathrm{CH}_{4}$ production suppression in shallow soils by the presence of oxygen, and in deeper soils by substrate limitation; (2) decreased production due to high concentrations of $\mathrm{Fe}$ in the deeper soil layers; and/or (3) increased Fe-AOM in the deeper layers where concentrations of both $\mathrm{CH}_{4}$ and Fe are highest. The presence of $\mathrm{Fe}$ and other mineral species in the deeper soil layers could contribute to substrate-related depressions in production, as mineral-organic associations protect soil organic carbon from decomposition [88]. There is also evidence that organic- and mineral- $\mathrm{CH}_{4}$ associations in deeper soil layers have a complex relationship with temperature, where warmer anoxic soils could result in higher rates of non-methanogenesis redox [83], particularly salient to net fluxes from warming permafrost peat soils. Contrastingly, Zhuang et al. [81] document an intriguing relationship between $\mathrm{CH}_{4}$ production and longer term Fe cycling, finding that additions of ferric iron initially depressed methanogenesis rates (as expected), but the production of secondary mineral compounds like magnetite later facilitated increased $\mathrm{CH}_{4}$ production via interspecies electron transfer between Geobacter and Methanosarcina. Thus, Fe cycling in deeper soils of the landscape could be both suppressing and promoting $\mathrm{CH}_{4}$ production depending on the mineral state and localized temperatures experienced at any given time within the soil system. Future work to determine drivers of net fluxes from both soil layer types and the landscape should focus on the interactions between mineral-organic dynamics and $\mathrm{CH}_{4}$ production and AOM.

The anoxic basins representative of the North Slope landscape near Utqiagivik are characterized by Fe-driven soil respiration $[40,52,77]$. We hypothesize that high native Fe concentrations and the importance of Fe-reduction respiration in these wetland soils favor AOM energetically linked with Fe-reduction, as has been seen in some high-Fe freshwater systems $[22,24,82]$. The relative insensitivity of overall AOM rates to additions of Fe(III) may be most simply explained by the abundance of pre-existing electron acceptors in these soils. However, Fe concentrations increase with depth in these soils $[40,52]$, and so the stimulation of AOM by Fe addition in the shallow layer may be evidence that $\mathrm{Fe}(\mathrm{III})$ is indeed an important electron acceptor for $\mathrm{AOM}$, as recently found in other environments $[17,20,25]$. In light of these data, the inhibitory effects of $\mathrm{Fe}(\mathrm{III})$ on landscape $\mathrm{CH}_{4}$ fluxes found by Miller et al. [51] might have been driven by Fe-dependent AOM.

Net $\mathrm{CH}_{4}$ release is a balance of the opposing forces of production and consumption, and so the environmental controls and drivers are likely to be complex. For example, Tan et al. [83] found a temperature-dependent inhibitory effect of humic substances on methane production in peat soils, while Valenzuela et al. [80] proved that humic substances can act as an electron acceptor for AOM in wetland soils. We know that warming will promote permafrost thaw, thus increasing the availability of complex soil carbon species (e.g., humic substances) and minerals for metabolic use [88-90]. It is unknown how the full suite of changing dynamics of the active layer will interact with $\mathrm{CH}_{4}$ cycling, as it seems likely that increased humic substance concentrations could inhibit methanogenesis, while also promoting AOM activities. Perhaps more importantly to overall net flux dynamics, the duration of any effects we expect is unknown-if a suppression of methane production eventually restricted AOM via substrate limitation, what could we expect the net balance of production and consumption pathways to be?

This landscape has an abundance of alternative electron acceptors, particularly Fe and humic substances [40,51,77]. Increased thaw could therefore release more Fe (and humic substances) currently trapped in the frozen mineral layer, and warming-induced cryoturbation could redistribute minerals 
into the upper active layer [91]. Based on what is already known about this system and the data presented here, Fe is likely the dominant electron acceptor for AOM. As soils thaw and deep mineral layers contribute to biogeochemical cycling in the active layer, increased Fe availability could theoretically dampen the release of $\mathrm{CH}_{4}$ through competitive inhibition of production and/or stimulation of Fe-dependent AOM. Alternatively, changes to the physical and metabolic dynamics of the active layer could potentially disturb any microbial consortia responsible for AOM, decoupling $\mathrm{CH}_{4}$ oxidation from these anaerobic processes [78], impacting net $\mathrm{CH}_{4}$ fluxes.

\subsection{Implications for $\mathrm{CH}_{4}$ Emissions in the Arctic Coastal Plain}

The recent shifts in some northern systems from their traditional role as $\mathrm{CO}_{2}$ sinks to $\mathrm{CO}_{2}$ sources $[7,10]$ are attributed to alterations in climate and changes in species distribution. If those same changes in local climate are conducive to $\mathrm{CH}_{4}$ production (e.g., wetter, warmer soils), it stands to reason that $\mathrm{AOM}$ rates will "follow the $\mathrm{CH}_{4}$ " and likewise accelerate activity. If so, and the methanogenesis to $\mathrm{AOM}(\mathrm{P}: \mathrm{C})$ ratio we observed remains steady, we would expect a larger quantity of $\mathrm{AOM}$-derived $\mathrm{CO}_{2}$ released to the atmosphere, positively contributing to the enhanced $\mathrm{CO}_{2}$ source effect, but diminishing the net release of the more potent greenhouse gas $\mathrm{CH}_{4}$.

As Arctic warming spurs thermokarst changes and new basin development, young basins may become more prevalent across the future North Slope [39], previously shown to have the highest levels of ecosystem respiration [56]. Young basins have thinner organic layers, with more overlap between the active layer sediments and the electron acceptor-rich mineral layer, and have been shown to have strong linkages between net $\mathrm{CH}_{4}$ fluxes and Fe dynamics [51]. In our pilot study, we observed the highest AOM rates from young and medium basin soils, and low AOM rates in deep layers of old and ancient basin soils, but replicated studies of these patterns are needed. Deep layers of older basin features in particular contain both high Fe concentrations and high soil organic carbon [90], likely somewhat protected from biomobilization by mineral-organic associations [88]. The emergence of young basins with high Fe contents in the upper soils would increase the precise landscape features and drivers we found associated with high levels of $\mathrm{AOM}$, suggesting a potential control on net $\mathrm{CH}_{4}$ fluxes from the landscape as a whole.

\section{Conclusions}

The major contributions of the work we presented here are: (1) finding evidence of AOM-capable microbes in the soils of the Arctic Coastal Plain drained thaw lake basin ecosystem; (2) measuring the first estimates of AOM rates from Alaskan North Slope soils, confirming the relative importance of this pathway to overall $\mathrm{CH}_{4}$ fluxes; and (3) making the connection between $\mathrm{Fe}$ and $\mathrm{AOM}$ in this system.

We used stable isotope tracers to quantify AOM rates, verifying the potential of Arctic peat soils to perform AOM (a previously unknown result), and corroborated this with genomic data, revealing the phylogenetic relatedness of Utqiagivik soil organisms and known anaerobic methanotrophs of ANME groups 2 and 3. We found that $25-34 \%$ of methane produced was converted to $\mathrm{CO}_{2}$ by $\mathrm{AOM}$, affecting net flux dynamics in this landscape, and that AOM activity was related to Fe. This work provides evidence that $\mathrm{AOM}$ has the potential to be a control on net $\mathrm{CH}_{4}$ fluxes from northern peatland soils, particularly as the Arctic warms and landscape features change to include more Fe-rich shallow soils.

Author Contributions: Conceptualization, K.E.M., C.-T.L., and D.A.L.; methodology, K.E.M., C.-T.L., and D.A.L.; formal analysis, K.E.M.; investigation, K.E.M.; resources, R.A.D., D.A.L., and K.E.M.; data curation, K.E.M.; writing—original draft preparation, K.E.M.; writing—review and editing, K.E.M., C.-T.L., R.A.D., and D.A.L.; visualization, K.E.M.; funding acquisition, D.A.L. and K.E.M.

Funding: This work was supported by NSF 0808604 to David Lipson, Largus Angenent and Ted K. Raab, and a Jastro-Shields Research Fellowship to K. Miller from UC-Davis.

Acknowledgments: We thank Faustine Bernadac, CPS, UMIAQ, and BASC for logistical support, and Marguerite Mauritz for comments on an earlier draft of this paper.

Conflicts of Interest: The authors declare no conflict of interest. 


\section{References}

1. Knittel, K.; Boetius, A. Anaerobic oxidation of methane: Progress with an unknown process. Annu. Rev. Microbiol. 2009, 63, 311-334. [CrossRef] [PubMed]

2. Valentine, D.L. Biogeochemistry and microbial ecology of methane oxidation in anoxic environments: A review. Antonie Van Leeuwenhoek 2002, 81, 271-282. [CrossRef]

3. Gupta, V.; Smemo, K.A.; Yavitt, J.B.; Fowle, D.; Branfireun, B.; Basiliko, N. Stable isotopes reveal widespread Anaerobic Methane Oxidation across latitude and peatland type. Environ. Sci. Technol. 2013, 47, 8273-8279. [CrossRef] [PubMed]

4. Gauthier, M.; Bradley, R.L.; Šimek, M. More evidence that anaerobic oxidation of methane is prevalent in soils: Is it time to upgrade our biogeochemical models? Soil Biol. Biochem. 2015, 80, 167-174. [CrossRef]

5. Serrano-Silva, N.; Sarria-Guzmán, Y.; Dendooven, L.; Luna-Guido, M. Methanogenesis and Methanotrophy in Soil: A Review. Pedosphere 2014, 24, 291-307. [CrossRef]

6. Hugelius, G.; Strauss, J.; Zubrzycki, S.; Harden, J.W.; Schuur, E.A.G.; Ping, C.-L.; Schirrmeister, L.; Grosse, G.; Michaelson, G.J.; Koven, C.D.; et al. Estimated stocks of circumpolar permafrost carbon with quantified uncertainty ranges and identified data gaps. Biogeosciences 2014, 11. [CrossRef]

7. Schuur, E.A.G.; McGuire, A.D.; Schädel, C.; Grosse, G.; Harden, J.W.; Hayes, D.J.; Hugelius, G.; Koven, C.D.; Kuhry, P.; Lawrence, D.M.; et al. Climate change and the permafrost carbon feedback. Nature 2015, 520, 171-179. [CrossRef]

8. Gorham, E. Northern peatlands: Role in the carbon cycle and probable responses to climatic warming. Ecol. Appl. 1991, 1, 182-195. [CrossRef]

9. Limpens, J.; Berendse, F.; Blodau, C.; Canadell, J.G.; Freeman, C.; Holden, J.; Roulet, N.; Rydin, H.; Schaepman-Strub, G. Peatlands and the carbon cycle: From local processes to global implications-A synthesis. Biogeosciences 2008, 5, 1475-1491. [CrossRef]

10. Oechel, W.C.; Laskowski, C.A.; Burba, G.; Gioli, B.; Kalhori, A.A.M. Annual patterns and budget of $\mathrm{CO}_{2}$ flux in an Arctic tussock tundra ecosystem. J. Geophys. Res. Biogeosci. 2014, 119, 323-339. [CrossRef]

11. Smemo, K.A.; Yavitt, J.B. Anaerobic oxidation of methane: An underappreciated aspect of methane cycling in peatland ecosystems? Biogeosciences 2011, 8, 779-793. [CrossRef]

12. Blazewicz, S.J.; Petersen, D.G.; Waldrop, M.P.; Firestone, M.K. Anaerobic oxidation of methane in tropical and boreal soils: Ecological significance in terrestrial methane cycling. J. Geophys. Res. Biogeosci. $2012,117$. [CrossRef]

13. Smemo, K.A.; Yavitt, J.B. Evidence for Anaerobic $\mathrm{CH}_{4}$ Oxidation in Freshwater Peatlands. Geomicrobiol. J. 2007, 24, 583-597. [CrossRef]

14. Zhu, B.; van Dijk, G.; Fritz, C.; Smolders, A.J.P.; Pol, A.; Jetten, M.S.M.; Ettwig, K.F. Anaerobic oxidization of methane in a minerotrophic peatland: Enrichment of nitrite-dependent methane-oxidizing bacteria. Appl. Environ. Microbiol. 2012. [CrossRef] [PubMed]

15. Xu, X.; Elias, D.A.; Graham, D.E.; Phelps, T.J.; Carroll, S.L.; Wullschleger, S.D.; Thornton, P.E. A microbial functional group-based module for simulating methane production and consumption: Application to an incubated permafrost soil. J. Geophys. Res. Biogeosci. 2015, 120, 1315-1333. [CrossRef]

16. Caldwell, S.L.; Laidler, J.R.; Brewer, E.A.; Eberly, J.O.; Sandborgh, S.C.; Colwell, F.S. Anaerobic Oxidation of Methane: Mechanisms, bioenergetics, and the ecology of associated microorganisms. Environ. Sci. Technol. 2008, 42, 6791-6799. [CrossRef]

17. Ettwig, K.F.; Zhu, B.; Speth, D.; Keltjens, J.T.; Jetten, M.S.M.; Kartal, B. Archaea catalyze iron-dependent anaerobic oxidation of methane. Proc. Natl. Acad. Sci. USA 2016, 113, 12792-12796. [CrossRef]

18. Ettwig, K.F.; Butler, M.K.; Paslier, D.L.; Pelletier, E.; Mangenot, S.; Kuypers, M.M.M.; Schreiber, F.; Dutilh, B.E.; Zedelius, J.; de Beer, D.; et al. Nitrite-driven anaerobic methane oxidation by oxygenic bacteria. Nature 2010, 464, 543-548. [CrossRef] [PubMed]

19. Thauer, R.K.; Shima, S. Methane as fuel for anaerobic microorganisms. Ann. N. Y. Acad. Sci. 2008, 1125, 158-170. [CrossRef]

20. He, Z.; Zhang, Q.; Feng, Y.; Luo, H.; Pan, X.; Gadd, G.M. Microbiological and environmental significance of metal-dependent anaerobic oxidation of methane. Sci. Total. Environ. 2018, 610-611, 759-768. [CrossRef] 
21. Vaksmaa, A.; Lüke, C.; van Alen, T.; Valè, G.; Lupotto, E.; Jetten, M.S.M.; Ettwig, K.F. Distribution and activity of the anaerobic methanotrophic community in a nitrogen-fertilized Italian paddy soil. FEMS Microbiol. Ecol. 2016, 92. [CrossRef] [PubMed]

22. Amos, R.T.; Bekins, B.A.; Cozzarelli, I.M.; Voytek, M.A.; Kirshtein, J.D.; Jones, E.J.P.; Blowes, D.W. Evidence for iron-mediated anaerobic methane oxidation in a crude oil-contaminated aquifer. Geobiology 2012, 10, 506-517. [CrossRef] [PubMed]

23. Crowe, S.A.; Katsev, S.; Leslie, K.; Sturm, A.; Magen, C.; Nomosatryo, S.; Pack, M.A.; Kessler, J.D.; Reeburgh, W.S.; Roberts, J.A.; et al. The methane cycle in ferruginous Lake Matano. Geobiology 2011, 9, 61-78. [CrossRef] [PubMed]

24. Sivan, O.; Adler, M.; Pearson, A.; Gelman, F.; Bar-Or, I.; John, S.G.; Eckert, W. Geochemical evidence for iron-mediated anaerobic oxidation of methane. Limnol. Oceanogr. 2011, 56, 1536-1544. [CrossRef]

25. Bar-Or, I.; Elvert, M.; Eckert, W.; Kushmaro, A.; Vigderovich, H.; Zhu, Q.; Ben-Dov, E.; Sivan, O. Iron-coupled Anaerobic Oxidation of Methane performed by a mixed bacterial-archaeal community based on poorly reactive minerals. Environ. Sci. Technol. 2017, 51, 12293-12301. [CrossRef] [PubMed]

26. Reiche, M.; Torburg, G.; Küsel, K. Competition of Fe(III) reduction and methanogenesis in an acidic fen. FEMS Microbiol. Ecol. 2008, 65, 88-101. [CrossRef]

27. Schlesinger, W.H.; Bernhardt, E.S. Biogeochemistry: An Analysis of Global Change; Academic Press: Cambridge, MA, USA, 2013; ISBN 978-0-12-385874-0.

28. Yao, H.; Conrad, R. Thermodynamics of methane production in different rice paddy soils from China, the Philippines and Italy. Soil Boil. Biochem. 1999, 31, 463-473. [CrossRef]

29. Van Bodegom, P.M.; Scholten, J.C.; Stams, A.J. Direct inhibition of methanogenesis by ferric iron. FEMS Microbiol. Ecol. 2004, 49, 261-268. [CrossRef]

30. Klüber, H.D.; Conrad, R. Effects of nitrate, nitrite, $\mathrm{NO}$ and $\mathrm{N}_{2} \mathrm{O}$ on methanogenesis and other redox processes in anoxic rice field soil. FEMS Microbiol. Ecol. 1998, 25, 301-318. [CrossRef]

31. Jugnia, L.-B.; Roy, R.; Pacheco-Oliver, M.; Planas, D.; Miguez, C.B.; Greer, C.W. Potential activity and diversity of methanotrophic bacteria in forest soil, peat, and sediments from a hyrdoelectric reservoir (Robert-Bourassa) and lakes in the Canadian taiga. Soil Sci. 2006, 171, 127. [CrossRef]

32. Tuomivirta, T.T.; Yrjälä, K.; Fritze, H. Quantitative PCR of pmoA using a novel reverse primer correlates with potential methane oxidation in Finnish fen. Res. Microbiol. 2009, 160, 751-756. [CrossRef] [PubMed]

33. Orphan, V.J.; House, C.H.; Hinrichs, K.-U.; McKeegan, K.D.; DeLong, E.F. Methane-consuming archaea revealed by directly coupled isotopic and phylogenetic analysis. Science 2001, 293, 484-487. [CrossRef] [PubMed]

34. Cadillo-Quiroz, H.; Yashiro, E.; Yavitt, J.B.; Zinder, S.H. Characterization of the archaeal community in a minerotrophic fen and terminal restriction fragment length polymorphism-directed isolation of a novel hydrogenotrophic methanogen. Appl. Environ. Microbiol. 2008, 74, 2059-2068. [CrossRef] [PubMed]

35. Dettling, M.D.; Yavitt, J.B.; Cadillo-Quiroz, H.; Sun, C.; Zinder, S.H. Soil-methanogen interactions in two peatlands (bog, fen) in central New York State. Geomicrobiol. J. 2007, 24, 247-259. [CrossRef]

36. Mohanty, S.R.; Bodelier, P.L.E.; Floris, V.; Conrad, R. Differential effects of nitrogenous fertilizers on methane-consuming microbes in rice field and forest soils. Appl. Environ. Microbiol. 2006, 72, 1346-1354. [CrossRef] [PubMed]

37. Knoblauch, C.; Zimmermann, U.; Blumenberg, M.; Michaelis, W.; Pfeiffer, E.-M. Methane turnover and temperature response of methane-oxidizing bacteria in permafrost-affected soils of northeast Siberia. Soil Boil. Biochem. 2008, 40, 3004-3013. [CrossRef]

38. Bockheim, J.G.; Hinkel, K.M.; Eisner, W.R.; Dai, X.Y. Carbon pools and accumulation rates in an age-series of soils in drained thaw-lake basins, Arctic Alaska. Soil Sci. Soc. Am. J. 2004, 68, 697-704. [CrossRef]

39. Hinkel, K.M.; Eisner, W.R.; Bockheim, J.G.; Nelson, F.E.; Peterson, K.M.; Dai, X. Spatial extent, age, and carbon stocks in drained thaw lake basins on the Barrow Peninsula, Alaska. Arctic, Antarct. Alp. Res. 2003, 35, 291-300. [CrossRef]

40. Lipson, D.A.; Jha, M.; Raab, T.K.; Oechel, W.C. Reduction of iron (III) and humic substances plays a major role in anaerobic respiration in an Arctic peat soil. J. Geophys. Res. Biogeosci. 2010, 115. [CrossRef]

41. Thomas, E.K.; Castañeda, I.S.; McKay, N.P.; Briner, J.P.; Salacup, J.M.; Nguyen, K.Q.; Schweinsberg, A.D. A wetter Arctic coincident with hemispheric warming 8000 years ago. Geophys. Res. Lett. 2018, 45, 10637-10647. [CrossRef] 
42. Vaughan, D.G.; Comiso, J.C.; Allison, I.; Carrasco, J.; Kaser, G.; Mote, P.; Murray, T.; Paul, F.; Ren, J.; Rignot, E.; et al. Observations: Cryosphere. In Climate Change 2013: The Physical Science Basis. Contribution of Working Group I to the Fifth Assessment Report of the Intergovernmental Panel on Climate Change; Cambridge University Press: New York, NY, USA, 2013; pp. 317-382.

43. Bockheim, J.G.; Hinkel, K.M.; Nelson, F.E. Predicting carbon storage in tundra soils of Arctic Alaska. Soil Sci. Soc. Am. J. 2003, 67, 948-950. [CrossRef]

44. Prater, J.L.; Chanton, J.P.; Whiting, G.J. Variation in methane production pathways associated with permafrost decomposition in collapse scar bogs of Alberta, Canada. Glob. Biogeochem. Cycles 2007, 21. [CrossRef]

45. Von Fischer, J.C.; Hedin, L.O. Separating methane production and consumption with a field-based isotope pool dilution technique. Glob. Biogeochem. Cycles 2002, 16. [CrossRef]

46. Bodelier, P.L.E.; Frenzel, P. Contribution of methanotrophic and nitrifying bacteria to $\mathrm{CH}_{4}$ and $\mathrm{NH}_{4}+$ oxidation in the rhizosphere of rice plants as determined by new methods of discrimination. Appl. Environ. Microbiol. 1999, 65, 1826-1833. [PubMed]

47. Krüger, M.; Meyerdierks, A.; Glöckner, F.O.; Amann, R.; Widdel, F.; Kube, M.; Reinhardt, R.; Kahnt, J.; Böcher, R.; Thauer, R.K.; et al. A conspicuous nickel protein in microbial mats that oxidize methane anaerobically. Nature 2003, 426, 878-881. [CrossRef]

48. Zehnder, A.J.; Brock, T.D. Methane formation and methane oxidation by methanogenic bacteria. J. Bacteriol. $1979,137,420-432$.

49. Nauhaus, K.; Treude, T.; Boetius, A.; Krüger, M. Environmental regulation of the anaerobic oxidation of methane: A comparison of ANME-I and ANME-II communities. Environ. Microbiol. 2005, 7, 98-106. [CrossRef]

50. Kelly, C.A.; Chynoweth, D.P. Comparison of in situ and in vitro rates of methane release in freshwater sediments. Appl. Environ. Microbiol. 1980, 40, 287-293.

51. Miller, K.E.; Lai, C.-T.; Friedman, E.S.; Angenent, L.T.; Lipson, D.A. Methane suppression by iron and humic acids in soils of the Arctic Coastal Plain. Soil Boil. Biochem. 2015, 83, 176-183. [CrossRef]

52. Lipson, D.A.; Raab, T.K.; Goria, D.; Zlamal, J. The contribution of Fe(III) and humic acid reduction to ecosystem respiration in drained thaw lake basins of the Arctic Coastal Plain. Glob. Biogeochem. Cycles 2013, 27, 399-409. [CrossRef]

53. Lipson, D.A.; Zona, D.; Raab, T.K.; Bozzolo, F.; Mauritz, M.; Oechel, W.C. Water-table height and microtopography control biogeochemical cycling in an Arctic coastal tundra ecosystem. Biogeosciences 2012, 9, 577-591. [CrossRef]

54. Sturtevant, C.S.; Oechel, W.C. Spatial variation in landscape-level $\mathrm{CO}_{2}$ and $\mathrm{CH}_{4}$ fluxes from arctic coastal tundra: Influence from vegetation, wetness, and the thaw lake cycle. Glob. Chang. Boil. 2013, 19, 2853-2866. [CrossRef]

55. Sturtevant, C.S.; Oechel, W.C.; Zona, D.; Kim, Y.; Emerson, C.E. Soil moisture control over autumn season methane flux, Arctic Coastal Plain of Alaska. Biogeosciences 2012, 9, 1423-1440. [CrossRef]

56. Zona, D.; Lipson, D.A.; Zulueta, R.C.; Oberbauer, S.F.; Oechel, W.C. Microtopographic controls on ecosystem functioning in the Arctic Coastal Plain. J. Geophys. Res. Biogeosci. 2011, 116. [CrossRef]

57. Von Fischer, J.C.; Rhew, R.C.; Ames, G.M.; Fosdick, B.K.; von Fischer, P.E. Vegetation height and other controls of spatial variability in methane emissions from the Arctic coastal tundra at Barrow, Alaska. J. Geophys. Res. Biogeosci. 2010, 115. [CrossRef]

58. Vaughn, L.J.S.; Torn, M.S. Radiocarbon measurements of ecosystem respiration and soil pore-space $\mathrm{CO}_{2}$ in Utqiagivik (Barrow), Alaska. Earth Syst. Sci. Data Discuss. 2018, 1-20. [CrossRef]

59. Quay, P.D.; King, S.L.; Lansdown, J.M.; Wilbur, D.O. Isotopic composition of methane released from wetlands: Implications for the increase in atmospheric methane. Glob. Biogeochem. Cycles 1988, 2, 385-397. [CrossRef]

60. Alperin, M.J.; Reeburgh, W.S. Carbon isotope fractionation by anaerobic methane oxidation. In Proceedings of the Abstracts of Papers of the American Chemical Society; Americal Chemical Society: Washington, DC, USA, 1987; Volume 193.

61. Grossman, E.L.; Cifuentes, L.A.; Cozzarelli, I.M. Anaerobic methane oxidation in a landfill-leachate plume. Environ. Sci. Technol. 2002, 36, 2436-2442. [CrossRef]

62. Martens, C.S.; Albert, D.B.; Alperin, M.J. Stable isotope tracing of anaerobic methane oxidation in the gassy sediments of Eckernforde Bay, German Baltic. Am. J. Sci. 1999, 299, 589-610. [CrossRef] 
63. Bond, D.R.; Lovley, D.R. Reduction of Fe(III) oxide by methanogens in the presence and absence of extracellular quinones. Environ. Microbiol. 2002, 4, 115-124. [CrossRef] [PubMed]

64. Finneran, K.T.; Johnsen, C.V.; Lovley, D.R. Rhodoferax ferrireducens sp. nov., a psychrotolerant, facultatively anaerobic bacterium that oxidizes acetate with the reduction of Fe(III). Int. J. Syst. Evol. Microbiol. 2003, 53, 669-673. [CrossRef] [PubMed]

65. Raghoebarsing, A.A.; Pol, A.; van de Pas-Schoonen, K.T.; Smolders, A.J.P.; Ettwig, K.F.; Rijpstra, W.I.C.; Schouten, S.; Damsté, J.S.S.; den Camp, H.J.M.O.; Jetten, M.S.M.; et al. A microbial consortium couples anaerobic methane oxidation to denitrification. Nature 2006, 440, 918-921. [CrossRef] [PubMed]

66. Gilbert, J.A.; Meyer, F.; Antonopoulos, D.; Balaji, P.; Brown, C.T.; Brown, C.T.; Desai, N.; Eisen, J.A.; Evers, D.; Field, D.; et al. Meeting Report: The Terabase Metagenomics Workshop and the Vision of an Earth Microbiome Project; BioMed Central: London, UK, 2010; p. 243.

67. Lipson, D.A.; Raab, T.K.; Parker, M.; Kelley, S.T.; Brislawn, C.J.; Jansson, J. Changes in microbial communities along redox gradients in polygonized Arctic wet tundra soils. Environ. Microbiol. Rep. 2015, 7, 649-657. [CrossRef]

68. Knittel, K.; Lösekann, T.; Boetius, A.; Kort, R.; Amann, R. Diversity and distribution of methanotrophic archaea at cold seeps. Appl. Environ. Microbiol. 2005, 71, 467-479. [CrossRef] [PubMed]

69. Pruesse, E.; Peplies, J.; Glöckner, F.O. SINA: Accurate high-throughput multiple sequence alignment of ribosomal RNA genes. Bioinformatics 2012, 28, 1823-1829. [CrossRef]

70. Hall, T.A. BioEdit: A User-Friendly Biological Sequence Alignment Editor and Analysis Program for Windows 95/98/NT; Nucleic Acids Symposium Series; Oxford University Press: Oxford, UK, 1999; pp. 95-98.

71. Lipson, D.A.; Haggerty, J.M.; Srinivas, A.; Raab, T.K.; Sathe, S.; Dinsdale, E.A. Metagenomic insights into anaerobic metabolism along an Arctic peat soil profile. PLOS ONE 2013, 8, e64659. [CrossRef] [PubMed]

72. Bidle, K.A.; Kastner, M.; Bartlett, D.H. A phylogenetic analysis of microbial communities associated with methane hydrate containing marine fluids and sediments in the Cascadia margin (ODP site 892B). FEMS Microbiol. Lett. 1999, 177, 101-108. [CrossRef] [PubMed]

73. Hallam, S.J.; Girguis, P.R.; Preston, C.M.; Richardson, P.M.; DeLong, E.F. Identification of methyl coenzyme M reductase A (mcrA) genes associated with methane-oxidizing archaea. Appl. Environ. Microbiol. 2003, 69, 5483-5491. [CrossRef]

74. Inagaki, F.; Tsunogai, U.; Suzuki, M.; Kosaka, A.; Machiyama, H.; Takai, K.; Nunoura, T.; Nealson, K.H.; Horikoshi, K. Characterization of C1-Metabolizing Prokaryotic Communities in Methane Seep Habitats at the Kuroshima Knoll, Southern Ryukyu Arc, by Analyzing pmoA, mmoX, mxaF, mcrA, and 16S rRNA Genes. Appl. Environ. Microbiol. 2004, 70, 7445-7455. [CrossRef] [PubMed]

75. R Core Team. R: A Language and Environment for Statistical Computing; R Foundation for Statistical Computing: Vienna, Austria, 2017.

76. Kao-Kniffin, J.; Woodcroft, B.J.; Carver, S.M.; Bockheim, J.G.; Handelsman, J.; Tyson, G.W.; Hinkel, K.M.; Mueller, C.W. Archaeal and bacterial communities across a chronosequence of drained lake basins in arctic alaska. Sci. Rep. 2015, 5, 18165. [CrossRef]

77. Friedman, E.S.; Miller, K.E.; Lipson, D.A.; Angenent, L.T. Potentiostatically poised electrodes mimic iron oxide and interact with soil microbial communities to alter the biogeochemistry of Arctic peat soils. Minerals 2013, 3, 318-336. [CrossRef]

78. Scheller, S.; Yu, H.; Chadwick, G.L.; McGlynn, S.E.; Orphan, V.J. Artificial electron acceptors decouple archaeal methane oxidation from sulfate reduction. Science 2016, 351, 703-707. [CrossRef] [PubMed]

79. Gao, Y.; Lee, J.; Neufeld, J.D.; Park, J.; Rittmann, B.E.; Lee, H.-S. Anaerobic oxidation of methane coupled with extracellular electron transfer to electrodes. Sci. Rep. 2017, 7, 5099. [CrossRef]

80. Valenzuela, E.I.; Prieto-Davó, A.; López-Lozano, N.E.; Hernández-Eligio, A.; Vega-Alvarado, L.; Juárez, K.; García-González, A.S.; López, M.G.; Cervantes, F.J. Anaerobic methane oxidation driven by microbial reduction of natural organic matter in a tropical wetland. Appl. Environ. Microbiol. 2017. [CrossRef] [PubMed]

81. Zhuang, L.; Xu, J.; Tang, J.; Zhou, S. Effect of ferrihydrite biomineralization on methanogenesis in an anaerobic incubation from paddy soil. J. Geophys. Res. Biogeosci. 2015, 120, 876-886. [CrossRef]

82. Segarra, K.E.A.; Schubotz, F.; Samarkin, V.; Yoshinaga, M.Y.; Hinrichs, K.-U.; Joye, S.B. High rates of anaerobic methane oxidation in freshwater wetlands reduce potential atmospheric methane emissions. Nat. Commun. 2015, 6, 7477. [CrossRef] [PubMed] 
83. Tan, W.; Jia, Y.; Huang, C.; Zhang, H.; Li, D.; Zhao, X.; Wang, G.; Jiang, J.; Xi, B. Increased suppression of methane production by humic substances in response to warming in anoxic environments. J. Environ. Manag. 2018, 206, 602-606. [CrossRef] [PubMed]

84. Martinez-Cruz, K.; Leewis, M.-C.; Herriott, I.C.; Sepulveda-Jauregui, A.; Anthony, K.W.; Thalasso, F.; Leigh, M.B. Anaerobic oxidation of methane by aerobic methanotrophs in sub-Arctic lake sediments. Sci. Total. Environ. 2017, 607-608, 23-31. [CrossRef] [PubMed]

85. Comas, X.; Kettridge, N.; Binley, A.; Slater, L.; Parsekian, A.; Baird, A.J.; Strack, M.; Waddington, J.M. The effect of peat structure on the spatial distribution of biogenic gases within bogs. Hydrol. Process. 2014, 28, 5483-5494. [CrossRef]

86. Smagin, A.V. Abiotic uptake of gases by organic soils. Eurasian Soil Sci. 2007, 40, 1326-1331. [CrossRef]

87. Vaughn, L.J.S.; Conrad, M.E.; Bill, M.; Torn, M.S. Isotopic insights into methane production, oxidation, and emissions in Arctic polygon tundra. Glob. Chang. Boil. 2016, 22, 3487-3502. [CrossRef] [PubMed]

88. Gentsch, N.; Wild, B.; Mikutta, R.; Čapek, P.; Diáková, K.; Schrumpf, M.; Turner, S.; Minnich, C.; Schaarschmidt, F.; Shibistova, O.; et al. Temperature response of permafrost soil carbon is attenuated by mineral protection. Glob. Chang. Boil. 2018, 24, 3401-3415. [CrossRef] [PubMed]

89. Stackhouse, B.T.; Vishnivetskaya, T.A.; Layton, A.; Chauhan, A.; Pfiffner, S.; Mykytczuk, N.C.; Sanders, R.; Whyte, L.G.; Hedin, L.; Saad, N.; et al. Effects of simulated spring thaw of permafrost from mineral cryosol on $\mathrm{CO}_{2}$ emissions and atmospheric $\mathrm{CH}_{4}$ uptake. J. Geophys. Res. Biogeosci. 2015, 120, 1764-1784. [CrossRef]

90. Mueller, C.W.; Rethemeyer, J.; Kao-Kniffin, J.; Löppmann, S.; Hinkel, K.M.; Bockheim, J.G. Large amounts of labile organic carbon in permafrost soils of northern Alaska. Glob. Chang. Boil. 2015, 21, 2804-2817. [CrossRef] [PubMed]

91. Bockheim, J.G. Importance of cryoturbation in redistributing organic carbon in permafrost-affected soils. Soil Sci. Soc. Am. J. 2007, 71, 1335-1342. [CrossRef]

(C) 2019 by the authors. Licensee MDPI, Basel, Switzerland. This article is an open access article distributed under the terms and conditions of the Creative Commons Attribution (CC BY) license (http:/ / creativecommons.org/licenses/by/4.0/). 